\title{
Public Policy and the Effects of Media Violence on Children
}

\author{
Douglas A. Gentile* \\ Department of Psychology, Center for the Study of Violence, Iowa State University; National Institute \\ on Media and the Family, Minneapolis, MN
}

Muniba Saleem

Department of Psychology, Center for the Study of Violence, Iowa State University

\section{Craig A. Anderson}

Department of Psychology, Center for the Study of Violence, Iowa State University

Policymakers and the public have been concerned about the effects of media violence on children for decades. Scientific psychological research can be an important source of information for policy, as the goal of science is to separate facts from opinions. This article reviews children's exposure to media violence, describes theories that explain the effects media violence could have, summarizes the research on the effects of media violence exposure, and describes several moderators that can enhance or mitigate those effects. These scientific findings provide useful information for public policy, yet there are many barriers to their use, including misunderstandings of how causality is determined in scientific and public health circles and how large the effects are. Finally, the implications for public policy are discussed, including what has and has not worked in the United States, what other countries and the international community are doing, and where opportunities for new approaches for effective policies may exist.

Policymakers and the public have been concerned about youth exposure to violent images for decades. Although numerous governmental and nongovernmental health science organization reports all conclude that research shows significant harmful effects of media violence exposure (e.g., Anderson et al., 2003; Australian

\footnotetext{
* Correspondence concerning this article should be addressed to Douglas A. Gentile, Iowa State University, Department of Psychology, W112 Lagomarcino Hall, Ames, IA 50011-3180. [e-mail: dgentile@iastate.edu].
} 
College of Paediatrics, 1994; Eron, Gentry, \& Schlegel, 1994; Huston et al., 1992; National Institute on Mental Health, 1982; U.S. Surgeon General's Scientific Advisory Committee, 1972), many people in the general public remain unaware of (or unconvinced by) the research, and there still is considerable public debate about whether to take the media violence issue seriously. Concern sporadically increases after school shootings or after apparent "copycat" incidents, as recently occurred when a 12-year-old boy killed a 6-year-old girl by imitating professional wrestling moves he had seen on television. These highly publicized events sometimes lead to the introduction of policy initiatives. However, because such extremely violent behavior is a complex phenomenon that occurs only when multiple risk factors converge, such incident-based policy initiatives have generally failed to convince the public or the courts that media violence constitutes a sufficiently significant risk factor to warrant action.

Scientific psychological research can be a critically important source of information for policymakers, as the goal of science is to separate facts from opinions. However, the existence of scientific facts, by themselves, should not lead directly to universally accepted policies (Anderson \& Gentile, 2008; Gentile \& Anderson, 2006). Furthermore, there are numerous groups involved in children's exposure to media violence, including the children themselves, their parents, media industries, distribution networks (including broadcast, cable, theaters, rental, and retail), and government agencies. Policymaking is further complicated by the fact that policies could be designed at each of these levels (individually or collectively).

In addition, media violence research is "unevenly distributed in the world" (von Feilitzen, 1998, p. 47), with the vast majority of such research being conducted in North America, some conducted in Western Europe, Japan, and Australia, but little elsewhere. Because of different cultural contexts in how media violence is portrayed, how aggression is expressed, and the range of public policy options existing under diverse systems of government and constitutions, it is difficult to know how far one can generalize the public policy implications of media violence research across countries (von Feilitzen, 1998). This article focuses primarily on research in North America, although research from other regions is included when possible. We summarize: (a) research on the effects of media violence; (b) theories that explain why the effects happen; (c) some possible barriers to public understanding of the scientific issues; and (d) the public policy landscape as it currently exists.

\section{Definitions: Scientific versus General Public}

In psychology, aggression is a well-defined scientific concept. Human aggression researchers define aggression as (a) a behavior that is intended to harm another individual, (b) the behavior is expected by the perpetrator to have some 
chance of actually harming that individual, and (c) the perpetrator believes that the target individual is motivated to avoid the harm (e.g., Anderson \& Bushman, 2002b; Baron \& Richardson, 1994; Berkowitz, 1993; Geen, 2001). Violence typically is defined by behavioral scientists as physical aggression that is so severe that the target is likely to suffer serious physical injury.

Media violence refers to media depictions of aggressive and violent behavior directed at characters in the media story. Those characters can be human or nonhuman, cartoonish or visually realistic. Fictional, unrealistic, or animated violence is still considered violence if it meets the above definitions.

Aggression can be further defined by its various forms. In direct aggression, the victim can easily identify the aggressor, whereas in indirect aggression the victim cannot easily identify the aggressor (Bjorkqvist, Osterman, Kaukiainen, 1992; Bushman \& Anderson, 1998; Crick \& Grotpeter, 1995; Lagerspetz, Bjorkqvist, Peltonen, 1988; Lagerspetz \& Bjorkqvist, 1992). Aggression can be further divided into physical, relational, and verbal aggression, with the distinctions defined by the method of intending harm.

The general public tends to use the word "aggression" in a broader way than aggression researchers, such as using it to mean assertive, confident, or energetic behavior. From a strictly scientific view, any use that does not fit the definition of aggression as a behavior with the three features outlined earlier is incorrect; these differences in usage lead to much confusion between aggression scientists, public policymakers, and the general public.

Research reveals that the public tends to focus on the graphic aspects and intensity of a scene in determining its level of violence (Potter \& Berry, 1999), contrary to scientific and legal definitions. Ironically, research has shown that children's cartoons have the highest frequency of television violence, but the public does not view cartoons as violent (Howitt \& Cumberbatch, 1975; National Television Violence Study, 1997). It seems that the affectively positive aspects of humor or animation lead to discounting such depictions as violence. This variation in definitions of violence may be explained by differences in concerns. Whereas the public is mainly concerned about the graphically explicit aspects in describing violence, the scientific community's conceptualization of violence is concerned with the extent to which it is likely to harm viewers (Potter, 1999).

\section{Exposure/Access to Violent Media}

In the largest study of its kind, over 5,000 12-year-olds from 23 countries in all regions of the world were surveyed (Groebel, 1998). The participating countries included Angola, Argentina, Armenia, Brazil, Canada, Costa Rica, Croatia, Egypt, Fiji, Germany, India, Japan, Mauritius, the Netherlands, Peru, Philippines, Qatar, South Africa, Spain, Tajikistan, Togo, Trinidad and Tobago, and the Ukraine. 
The sample was remarkable for its diversity, not only in regions, but also by including children from urban areas, rural areas, and even refugee camps. Perhaps surprisingly, 93\% of children had access to a TV set (ranging between 99\% for the North-Western hemisphere and $83 \%$ for Africa), with children worldwide spending an average of three hours per day watching. One conclusion from this study was that "TV has become a major socialization factor and dominates the life of children in urban and electrified rural areas around the globe" (p. 182). A parallel conclusion was that "media violence is universal" (p. 183). Indeed, almost 9 out of $10(88 \%)$ of the world's children knew Arnold Schwarzenegger's violent Terminator movie character.

Using standardized definitions of aggression, several content analyses have examined both the frequency and types of portrayals of violence in media. One of the largest was the National Television Violence Study, which observed 23 American broadcast and cable channels over a 20-week period (NTVS 1997, 1998; Wilson et al., 1997, 1998). Overall, $61 \%$ of all television programming contained some violence. This percentage increased to $81 \%$ for prime time and for Saturday morning time slots. In fact, children's programs on Saturday mornings are the most violent genre, with violent acts occurring an average of 20 times in a 1-hour period. Prime-time programming is a distant second, with five violent acts per hour. Children's programming has a higher frequency of violence than comedies, music videos, and reality programs.

Such statistics are sometimes ridiculed by media industries and social commentators, mainly because they do not understand or accept the scientific definition of aggression. When asked to rate how violent various media are, most adults focus on how graphic the depictions are, rather than on several other relevant dimensions, such as whether the behaviors exhibit intentional harm (the definition of aggression), the potential for serious injury (the definition of violence), or the frequency of aggression and violence. This nonscientific focus on graphicness leads people to believe (incorrectly) that cartoons are somehow less violent than adult crime shows. More importantly, there is evidence that even cartoonish violence can have the same types of effects as more realistic or graphic violence (Anderson, Gentile, \& Buckley, 2007; Carnagey \& Anderson, 2004; Liss, Reinhardt, \& Fredriksen, 1983; Silvern \& Williamson, 1987).

Some critics argue that media violence is simply representative of real-world violence. However, research shows that violent crimes are greatly overrepresented on TV compared to real life. More than half of prime-time drama and comedy portray at least one crime, with murder and assault displayed most frequently; but, burglary and larceny are the two most prevalent crimes in America (Potter, 1999). In American "reality"-based police shows, $87 \%$ of the criminal suspects are associated with violent crimes; however, in reality only $13 \%$ of crimes are violent (Oliver, 1994). Film critic Michael Medved (1995) noted that "about 350 characters 
appear each night on prime-time TV, but studies show an average of seven of these people are murdered every night. If this rate applied in reality, then in just 50 days everyone in the United States would be killed and the last left could turn off the TV" (pp. 156-157) overexemplifying the frequency and intensity of violence, television normalizes an unrealistic and exaggerated culture of violence in its viewers. The average American child is estimated to have seen 8,000 simulated murders and over 2,00,000 acts of violence on TV alone by the time he or she is graduated from high school (Huston et al., 1992). Although the 1996 Telecommunications Act mandated that televisions include a "V-chip" to allow parents to control the amount of violence children see, almost no parents use them (Federal Communications Commission [FCC], 2007). In fact, the U.S. Federal Communications Commission recently concluded (2007, p. 14), "Based on the studies and surveys conducted to date, we believe that the evidence clearly points to one conclusion: the Vchip is of limited effectiveness in protecting children from violent television content."

Content analyses of Japanese television demonstrate that although the total amount of violence was not different from American TV, the context was very different (Kodaira, 1998). Japanese TV tends to portray violent actions and their consequences much more vividly, with a particular emphasis on the suffering of the victims. This difference is also seen in broader content analyses across eight Asian countries, with programs of Asian origin showing much greater depiction of the suffering caused by violence (Goonasekera \& Lock, 1990). As will be described later, this contextual difference may influence the effects of viewing media violence on viewers.

Concern also has extended to violence in video games. Despite their short history, they have had a significant effect on the entertainment industry. To keep their competitive edge in the entertainment industry, video games have increasingly pushed for better graphics, more intense sound, more interactivity, and increasingly realistic kinematics. Through the synergy of these aspects, it is possible for current video game players to undergo much more realistic experiences than the previous generation of game players. Video games have historically been seen as something only children play, and 9 out of 10 (92\%) American youth aged 8 to 18 years do play (Gentile \& Walsh, 2002). Recent studies show that even high school seniors who are going to college are devoting more time to video games (CIRP, 1998, 2005). Furthermore, the fastest-growing segment of the American video game market is adults, with $32 \%$ of adults playing, increasing the average age of gamers to 33 (Entertainment Software Association, 2006) — a statistic that is often used to deflect from the fact that almost all American children are exposed to video games. A much higher percentage of youth between the ages of 8 and 17 years regularly play video games than any other 10 -year age span. The average age of gamers is so high merely because there are a lot more adults (e.g., age 18-100) than children in America. 
Video games have become big business, earning over $\$ 13$ billion in the United States alone in 2006 (ESA, 2006). This is more than Hollywood made on all movies in all American theaters (\$9.5 billion) (Motion Picture Association, 2006). As video games have become more dominant, the amount of time children play them has also increased. Children in the 1980s averaged 4 hours of video gaming per week (Gentile \& Anderson, 2003), whereas today's generation averages 13 hours per week, with boys 8 to 18 years averaging 19 hours per week (Martin \& Oppenheim, 2007). Games have also become more violent, with 52\% of games (rated E through $\mathrm{M}$ ) including violent contact by ESRB standards (the ESRB is the American Entertainment Software Ratings Board) (Gentile, in press), although independent analyses suggest that the ESRB underreports violence in video games by almost half (Thompson \& Haninger, 2001). Although American children are playing video games now more than ever, they are not sacrificing television time to do so, with the average holding relatively steady at 25 hours per week of television (Gentile \& Walsh, 2002; Kaiser Family Foundation, 2005). Furthermore, 7 out of 10 fourth- to twelfth-grade children (aged 8 to 17 years) report playing M-rated ("Mature") video games, which include the most graphic violence (Walsh et al., 2005). Therefore, a tremendous number of children (almost all) are exposed to high levels of media violence, and that exposure appears to be increasing over time.

\section{Media Violence Effects: Theory}

It is important to understand the role of theory in science and public policy. Scientific theory can be defined as an organized set of hypotheses that allow a scientist to understand, explain, and predict the variety of findings that studies produce (Shaw \& Costanzo, 1982). Theories are necessary for understanding and improving current research findings and predicting future directions. Wellvalidated theories also are essential to the creation of effective public policy. We discuss this aspect of theory more fully in a later section. For now, it is sufficient to quote Kurt Lewin (1951), who noted that "There is nothing so practical as a good theory."

The effects of media violence on aggression can be understood through several well-developed theories that draw on several disciplines. Multiple disciplines are necessary for a complete understanding because there are multiple mechanisms underlying media violence effects. Current models have been tested, refined, and retested repeatedly over the years. The most thorough are versions of socialcognitive, information processing models that focus on how people perceive, think, learn, and come to behave in particular ways. People's current behavioral tendencies result from past interactions with the social world. These social interactions may be real (e.g., parents, peers) and fictional (e.g., various forms of 
media). Although there are several appropriate theories concerning media violence, only three are discussed here. ${ }^{1}$ Reviews of other theories are available (Anderson \& Bushman, 2002b; Anderson \& Huesmann, 2003; Berkowitz, 1984, 1993; Huesmann, 1997, 1998).

\section{Social Learning Theory}

Children begin imitating and learning from others at a very young age. For example, children readily imitate aggressive behaviors they see others perform, either live or from televised images. Indeed, the discovery of the mirror neuron system provides a specific physiological system for such imitative learning (e.g., Rizzolatti \& Craighero, 2004). Observing and imitating other people's behavior is one of the most important sources involved in the development of a young child's motor and social skills. Similarly, children observe social interactions and their consequences from numerous sources: parents, peers, older siblings, and even fictional characters portrayed in the media. Children are more likely to imitate a behavior that is followed by a reward than a behavior followed by a punishment (Bandura, 1965; Bandura, Ross, \& Ross, 1963b; 1963c). With time children learn how to behave in certain situations and develop a set of rules for behaviors in specific events.

\section{Cognitive-Neoassociation Theory}

Numerous aversive events (e.g., frustration, provocations, loud noises, uncomfortable temperatures, and unpleasant odors) lead to negative affect and subsequently to aggression (Berkowitz, 1989, 1993). For example, uncomfortably hot temperatures increase irritability and, under the right conditions, aggressive behavior (Anderson, 1989; Anderson, Anderson, Dorr, DeNeve, \& Flanagan, 2000). Through frequent associations, negative affect becomes linked to a variety of thoughts, memories, expressive motor reactions, and physiological responses. These responses are then automatically activated when negative affect is present in future circumstances and give rise to two immediate and simultaneous tendencies, fight or flight. The fight associations give rise to beginning stages of feelings of anger, whereas the flight associations give rise to beginning stages of feelings of fear. The tendency that is the stronger of the two is most likely to determine the individual's behavior in the present situation. Through classical conditioning, cues present in the current aversive event are likely to become associated with the experiences (e.g., thoughts, emotions, memories, and motor reactions). Similar

\footnotetext{
${ }^{1}$ These three are selected for their illustrative value. Social Learning Theory is the original theory designed to account for observational learning. Cognitive-Neoassociation Theory is set at a neural level of analysis, and is thus complementary to SLT. The General Aggression Model is the newest and most comprehensive of the multiple theories.
} 
cues in the future, even under different circumstances, are likely to trigger similar reactions and responses.

\section{General Aggression Model}

The General Aggression Model (GAM) is a relatively new theory that integrates concepts and ideas from earlier models (Carnagey \& Anderson, 2003; Anderson et al., 2007). GAM describes a cyclical pattern of interaction between the person and their environment. The model is especially helpful in understanding how individual and situational variables affect a person's appraisal of a situation and ultimately affect the behavior performed in response to that appraisal. Input factors (personal and situational) are thought to influence an individual's present internal state, which consists of cognition, affect, and arousal. Each of these three routes can be influenced by input variables and can also influence one another. The present internal state then influences one's decision-making process leading eventually to either a thoughtful action or an impulsive action. Impulsive actions and behaviors could be a result of immediate and spontaneous appraisals that are made without much thought or awareness. Thoughtful actions and behaviors, on the other hand, would be a result of searching for relevant information to reevaluate the current circumstance, but this occurs only when given enough time and motivation to reevaluate immediate appraisals. This does not mean thoughtful actions will be always nonaggressive and impulsive actions will be always aggressive. Both impulsive and thoughtful behaviors can be either aggressive or nonaggressive.

The General Aggression Model (and most of the other contemporary theories related to aggression) is not designed as a media violence theory, but as a broad theory of human aggression designed to explain the likelihood of aggressive responding in the short term, and the development of aggressive personality in the long term. As such, it can be used to understand all of the variables that increase aggression, including exposure to violent media. Theoretically, violent media can affect all three components of internal state. Playing violent video games can temporarily increase aggressive thoughts, affect, and arousal (Anderson \& Bushman, 2001). In the long term, repeated exposure to violent media can reduce arousal to subsequent depictions of violence, increase aggressive thought patterns and beliefs in the efficacy of aggression, and increase hostile interpretations of ambiguous social events (Bushman \& Anderson, 2002). In sum, the General Aggression Model accounts for a wide variety of effects seen in the media violence literature including both short-term and long-term effects on aggressive thoughts, feelings, and behaviors; on emotional desensitization to violence and subsequent declines in prosocial behavior; and on changes in the social environment that occur as the developing child becomes more habitually aggressive. 


\section{Overall Summary of Media Violence Effects}

Many summaries of the effects of viewing media violence have been compiled by independent governmental and nongovernmental health organizations. All have found significant harmful effects on children and youth (e.g., the 1954 Kefauver hearings; the 1969 National Commission on the Causes and Prevention of Violence; the 1972 Surgeon General's report Television and Growing Up [U.S. Surgeon General's Scientific Advisory Committee, 1972]; the 1982 National Institute of Mental Health [NIMH] report Television and Behavior; Eron, Gentry, \& Schlegel's 1994 report for the American Psychological Association; the 1994 Policy Statement by the Australian College of Paediatrics, the 2000 Joint Statement on the Impact of Entertainment Violence on Children by six health associations; the 2004 Ontario Office for Victims of Crime report Action Agenda: A Strategic Blueprint for Reducing Exposure to Media Violence in Canada; and the 2005 American Psychological Association Resolution on Violence in Video Games and Interactive Media [Carll et al., 2005]).

Depending upon how specific or broad one categorizes media violence effects, one can identify 14 (or more) scientifically documented effects of exposure to media violence, found in at least five conceptually distinct domains: physiological, emotional, cognitive, attitudinal, and behavioral. These can be further broken down into short-term and long-term effects (for a detailed discussion, see Potter, 1999; 2003). Other summaries focus on four main types of effects: increases in aggressive thoughts, aggressive behavior, aggressive feelings, and physiological arousal. In addition, media violence exposure has been linked to decreases in helpful and prosocial behaviors. Furthermore, violent media exposure has been shown to cause an increase in aggression-supporting beliefs and a reduction of normal negative emotional responses to violence (Anderson et al., 2003; Carnagey, Anderson, \& Bushman, 2007), as well as increases in fear (Cantor, 2003).

Some media violence effects can be seen in immediate settings, whereas others accumulate over time. The multiplicity of media violence effects requires multiple research methods in a wide variety of settings. How is the research actually conducted?

\section{Understanding the Research: The ABCs of Media Violence Effects on Aggression}

Most media violence studies focus on the impact of exposure to media violence on aggressive affect, aggressive cognitions, and/or aggressive behaviors. Aggressive affect comprises emotional reactions, such as anger, which are related to aggressive behavior. Aggressive cognitions (or aggressive thoughts) include a wide range of phenomena, such as cognitive accessibility of simple aggressive 
concepts in memory; beliefs and attitudes that promote aggression; and plans and expectations (e.g., scripts) concerning conflict situations. As noted earlier, aggressive behaviors are actions with which one intends and expects to harm another individual. Because of space limitations, we focus on aggressive behavior (i.e., aggression).

\section{Measures of Aggression}

Aggression has been measured validly in many different ways, reflecting the multifaceted aspects of aggression and the multiple contexts in which valid measures are needed (Anderson \& Bushman, 1997; Berkowitz, 1993; Bushman \& Anderson, 1998; Carlson, Marcus-Newhall, \& Miller, 1989). Early laboratory studies of direct physical aggression frequently involved some form of the aggression machine paradigm (Buss, 1961). These paradigms usually involve a learning and punishment interaction between the participant and a confederate of the research team. The confederate is instructed to learn some type of a stimuli and the participant is told to punish the confederate's incorrect responses through some type of noxious stimulus that would clearly be unpleasant for the confederate (e.g., electrical shocks, noise blasts, heat pulses). Modifications to this paradigm include initially provoking the participant, setting duration time for the noxious stimuli, and using indirect methods such as subtracting from the confederate's pay or points when he or she makes a mistake.

In recent years, the most popular laboratory measure of physical aggression has been some version of the Taylor competitive reaction time task (Bushman, 1995; Taylor, 1967). In this task, participants believe that they are competing with an opponent in a series of reaction time trials. Supposedly as a motivator, the loser of each trial receives a punishment of some type (e.g., electric shock, white noise). Participants further believe that they and their opponent set the punishment level for each other prior to each trial. The measure of aggression is derived from the punishment levels that participants set for their opponents. Even though there are numerous ways to measure laboratory aggression, research has found that they are consistent in measuring the same conceptual variable (Carlson et al., 1989).

Real-world measures of aggressive behavior frequently involve such things as self/peer/parent/teacher-reports of fights, observer ratings or counts of aggressive behavior, and violent crime reports. These measures are also positively related to each other across a wide range of studies. Despite a lack of surface-level similarities, research shows that effects found with laboratory measures do in fact predict real-world aggression effects, and vice versa (Anderson \& Bushman, 1997; Anderson, Lindsay, \& Bushman, 1999). Situational variables known to increase aggression and violence in the real world (e.g., provocation, alcohol, the visible presence of a weapon, and media violence) have the same type of effect on laboratory aggression. Similarly, people with a history of real-world aggression 
(e.g., violent crime) also behave more aggressively in the laboratory than those without a history of aggression in the real world. The convergence of real-world and laboratory measures of aggression reflects the underlying conceptual similarity of what appears to be very different surface-level behaviors: whether it is throwing a punch (real-world measure) or delivering an electric shock (laboratory measure), the aggressor in both cases intends to harm the victim.

\section{Media Violence Effects: Empirical Research}

There are several different research designs that can be used to study media violence. We focus on the most common types of designs used in the current literature: experimental, cross-sectional, and longitudinal studies. Each type has characteristic strengths (when well constructed) and weaknesses (even when well constructed). The weaknesses in one design are typically offset by strengths in other designs. In any complex research domain, use of multiple research approaches is advantageous because it allows one to triangulate on true causal relations between the variables under study (Anderson, 1989; Anderson et al., 1989; Anderson et al., 2007; Anderson \& McLean, 1974; Carlsmith, Ellsworth, \& Aronson, 1976; Proctor \& Capaldi, 2006). The strongest case for concluding that an independent variable (such as exposure to media violence) causes an increase in an important dependent variable (such as aggressive and violent behavior) occurs when different designs yield converging results. This case exists in media violence research (Anderson et al., 2003; Anderson \& Bushman, 2002a; Gentile, 2003).

\section{Experimental Studies}

The primary strength of experimental studies is that they allow strong causal inferences because researchers can have complete control over their treatments, leaving little room for alternative explanations. The researcher randomly assigns participants to different treatment and control conditions (e.g., violent or nonviolent video game play). Such random assignment reduces any potential systematic differences between the types of individuals in different conditions, and therefore allows one to infer that any obtained differences in results were caused by differences in the independent variable. However, because it would be unethical to allow participants to injure each other physically, either laboratory measures of aggression or mild real measures of aggression (in studies with children) are used. Thus, the major weakness of most aggression experiments is that serious forms of "real-world" aggression cannot be assessed. Given the proven external validity of laboratory measures of aggression, this weakness is not (in our view) a particularly serious one.

A number of laboratory and field experiments over the past half-century have examined whether exposure to violent behavior on film or television tends to 
increase aggression-related variables in the short term (see reviews by Anderson et al., 2003; Berkowitz, 1993; Bushman \& Huesmann, 2001; Comstock, 1980; Geen, 2001; Geen \& Thomas, 1986; Rule \& Ferguson, 1986). An example of an experiment involves randomly assigning children to play a violent or nonviolent video game that had been previously rated as equal on many dimensions, such as how fun, frustrating, or boring they are (Anderson et al., 2007). In this experiment, children played their assigned game for 20 minutes, and then were given opportunities to punish another child. Children who played the violent game gave much more noxious punishments. The consistent finding from experiments where youth are randomly assigned to watch violent scenes is that youth subsequently display more aggressive behavior, aggressive thoughts, or aggressive emotions than those in the nonviolent media condition.

Most studies look for very specific types of effects. For example, sexualized violence in the media has been linked to increases in violence toward women, rape myth acceptance, and misogynistic attitudes. The presentation of violence and explicit sexual stimuli seem to have an additive effect (Comstock \& Scharrer, 2003). Pornographic material containing violence has been found to have a greater impact on subsequent aggression than nonviolent sexual stimuli. For example, in one experimental study, male university students watched either a movie portraying sex and violence, a nonviolent sex film, or a movie that was neither sexual nor violent and were then given an opportunity to retaliate against a woman who had angered them earlier, by giving her electric shocks (Donnerstein \& Berkowitz, 1981). The men who had viewed the violent sex film punished the woman more intensely than did their counterparts who had watched either the neutral film or the nonviolent sex movie.

\section{Cross-Sectional Correlational Studies}

The major strength of cross-sectional (correlational) studies is that they can include real-world aggression and violence measures as the dependent variable. Establishing causality through cross-sectional studies, however, is much harder than with experimental methods because the lack of random assignment of participants to various levels of the independent variable allows for plausible alternative explanations. For example, participants with a history of high media violence exposure may behave more aggressively in school because: (a) of true media violence effects on aggression (the main causal hypothesis); (b) they spend so much time on entertainment media that they fail to learn social skills; or (c) prior trait aggressiveness leads to both aggressive behavior in school and a greater than normal interest in violent media.

Nonetheless, a causal hypothesis can be contradicted by correlational studies-by finding nonsignificant correlations between the hypothesized causally linked variables, for example. Therefore, such studies do constitute legitimate tests 
of a causal theory. Furthermore, correlational studies can be used to test alternative explanations of a causal hypothesis. For example, a number of studies have shown that neither total time spent on entertainment media nor trait aggressiveness account for the frequently observed correlation between violent media exposure and aggression (e.g., Anderson \& Dill, 2000; Anderson et al., 2007; Gentile, Lynch, Linder, \& Walsh, 2004). Cross-sectional surveys over the past 40 years have consistently provided evidence that the current physical aggression, verbal aggression, and aggressive thoughts of young people are correlated with the amount of television and film violence they regularly watch (see reviews by Chaffee, 1972; Comstock, 1980; Eysenck \& Nias, 1978; Huesmann \& Miller, 1994).

\section{Longitudinal Studies}

Longitudinal studies measure the same participants at least twice over an appropriate period of time. There are two primary advantages to well-conducted longitudinal studies. First they can include consequential, real-world aggression as the dependent variable. Second, they allow strong causal inferences, because by measuring the same sample on theoretically relevant variables at several points in time they allow strong tests of alternative explanations. For example, one common alternative explanation of media violence effects is that the correlation between media violence exposure and aggression is caused by highly aggressive individuals choosing relatively more aggressive media, rather than high media violence exposure causing increased aggression. In a two-points-in-time longitudinal study, the aggressive tendency and media habits of each participant are measured at both points in time. If the alternative explanation is true, then the relation between media violence exposure at Time 1 and aggressiveness at Time 2 should be zero when aggressiveness at Time 1 is statistically controlled.

There have been a small number of longitudinal studies examining the effects of television violence on aggressive behavior over time. An extensive longitudinal study started in 1977 when Huesmann and his colleagues began to study the effects of TV violence in Australia, Finland, Israel, the Netherlands, Poland, and the United States (Huesmann \& Eron, 1986; Huesmann, Moise-Titus, Podolski, \& Eron, 2003; Huesmann, Lagerspetz, \& Eron, 1984). Representative samples of middle-class youth in each country were examined at three times as they grew from 6 to 8 or from 8 to 11 years of age. Aggression was assessed by peer nominations in response to questions about physical and verbal behaviors, among other things. Though there were some interesting contextual differences, the cross-sectional correlations between aggression and overall exposure to TV violence were positive and small to moderate in all countries, with significant correlations being obtained for both boys and girls in the United States.

Fifteen years after the study started, more than 300 participants in the U.S. sample were reinterviewed when they were in their early twenties (Huesmann 
et al., 2003). Results from this 15-year follow-up suggest a delayed effect of media violence on serious physical aggression. The researchers found significant correlations between television violence viewing during childhood and a composite measure of aggression (physical, verbal, and indirect) during young adulthood, for both men and women. Analyses also showed that for both men and women, frequent exposure to TV violence during childhood resulted in high levels of aggressive behavior later, whereas high aggressiveness during childhood did not lead to frequent viewing of television violence later.

In a classic longitudinal field study, children in two similar Canadian towns an hour away from each other were studied (Williams, 1986; MacBeth, 2003). The primary difference between the two towns is that one had had TV reception for about 15 years, and the other was only just getting television in 1973. Observations of playground behavior over two years (as well as peer and teacher measures) demonstrated that both boys' and girls' verbal and physical aggression increased after the introduction of television.

At the time of this writing, there is only one published longitudinal study of violent video games, and it only looked across approximately 6 months (Anderson et al., 2007, study 3). In this study, 430 third to fifth grade children (primarily ages $8-10$ years), their peers, and teachers were surveyed at two points in time, early and later in a school year. Children who played more violent video games early in the school year were more aggressive by later in the school year, even after controlling for how aggressive they were at Time 1.

\section{Broader International Research}

Although the majority of research has been conducted in the United States, the types of results described earlier have been found in numerous other countries as well. The studies from other countries have tended to yield similar results to those conducted in the United States, but they also have shown the importance of cultural context. In the longitudinal study of children in six countries mentioned above, in general, children's TV habits tended to predict subsequent aggression even after controlling for earlier aggression. This result is somewhat remarkable given that the media offerings were very different in these countries at the time-Finland, Israel, and Poland had much less violence on TV than America. The results did, however, demonstrate that the cultural context can matter greatly. For example, within Israel there were significant correlations between TV violence viewing and children's aggression for urban children, but not for children being raised on a kibbutz, where socialization is conducted in a communal manner (Bachrach, 1986). As Israeli television changed to allow more channels from other cultures, the effects seem to have changed as well. In a correlational study of Israeli children and school principals in 1994, the American World Wrestling Federation television show "increased violence in the schools and the rate of injuries to a degree never known 
before and not repeated since its decline" (Lemish, 1998, p. 130). Although the children themselves reported that the WWF series represented a foreign ideology and culture, it nevertheless had a large impact on their culture.

In a survey of several European countries, researchers reported on the state of media research in their countries (Linné, 1998). Several researchers and heads of children's television reported that there was little research in their countries (e.g., Albania, Austria, Bosnia and Herzegovina, Bulgaria, Croatia, Greece, Italy, Luxembourg, Former Yugoslav Republic of Macedonia, Portugal, Romania, and Spain). Other European countries, such as the UK, Germany, the Nordic countries, and the Netherlands had more established research. The major approaches to research were dominantly sociological, followed by psychological approaches. This is important as it demonstrates a difficulty when attempting to generalize across studies. Sociological approaches tend to relate children's media use and enjoyment to the social context within which it occurs, whereas psychological approaches tend to focus on the functions media serve and the effects they have. Thus studies that at first appear discrepant are often in actuality complementary. In this context, much of the European research appears more "positive" than the American research. Nonetheless, when those European researchers who had personally studied or written about media violence were asked, "What is your personal opinion based on your interpretation of the research evidence on the causal link between violence in the media and violence in society?" only four percent thought that "there is no causal link" (Linné, 1998, p. 151). The other researcher responses suggested that most scholars are aware of the complexity of the issue, and that this was in a real sense too simplistic a question.

Japan also has a history of conducting media violence research. The results of correlational and longitudinal studies have tended to yield much weaker results, although none have followed participants for more than about 3 years (Kodaira, 1998). As will be described later, these apparently discrepant results may be partially explained by differences in the context of media violence. More recently, Japanese scholars have begun examining violent video game effects in Japan. A meta-analysis comparing violent video game effects from these studies to effects from Western cultures finds similar effects across cultures (Anderson et al., under review).

In the 23 country study, about one-third of the children lived in high-aggression or high-risk environments, ranging from high-crime areas to war zones (Groebel, 1998). Children in the high-aggression areas were more likely to report that what they saw in the media was like reality than children in the low-aggression areas. In addition, children in high-aggression areas were more likely to want to be like aggressive media models, such as the Terminator character. Most germane to this article, however, are the results linking a preference for media violence and the desire to be involved in aggression oneself, regardless of region of the world. Almost half (47\%) of children who prefer aggressive media content would like to 
be in aggressive situations, compared to $19 \%$ of children who have other media preferences. Causal inferences from this single correlational study would be risky. Nonetheless, it is instructive that across such a wide range of cultures, economies, languages, religions, and histories, the results are very similar to those of similar research in North America.

\section{Narrative Reviews}

In addition to individual experimental, cross-sectional, and longitudinal research designs, there are two methods that allow for summarizing across multiple studies: narrative reviews and meta-analytic reviews. Narrative reviews attempt to describe all relevant published empirical studies and are useful in describing their similarities and differences, especially concerning methodologies. The major weakness of narrative reviews is that they are dependent on interpretation, and therefore reviewer bias can lead to different kinds of interpretations of the same literature. Nonetheless, all narrative reviews conducted since 1980 and published in peer-reviewed journals have concluded that media violence is consistently related to subsequent aggressiveness (Potter, 1999).

\section{Meta-Analyses}

In contrast to narrative reviews, meta-analytic reviews statistically integrate all related empirical research to reach a stronger conclusion and to improve generalizations of individual studies. When properly conducted, meta-analytic reviews reduce the potential reviewer bias inherent in narrative reviews by using statistical methodologies to reach a more objective conclusion. (For a detailed description of meta-analytic reviews and how they have been applied to the media violence domain, see Comstock \& Scharrer, 2003.) Similar to the narrative reviews, all the meta-analyses that have been conducted on the media violence literature have found that media violence is significantly and positively related to aggression. ${ }^{2}$

\section{Media Violence Effects Summary}

Scientists are taught to be skeptical of any specific study, because each study has its own strengths and weaknesses. Instead, firm conclusions require

\footnotetext{
${ }^{2}$ One recent meta-analytic review claimed a nonsignificant effect of video game violence on aggressive behavior, but in fact, found significant effects of violent video game exposure on increasing physiological arousal $\left(r_{+}=.27\right)$, aggressive thoughts $\left(r_{+}=.25\right)$, aggressive behavior $\left(r_{+}=.29\right)$, and decreasing prosocial behavior $\left(r_{+}=.30\right)$, similar to other meta-analyses (actually, even larger effects, due to only looking at the past 10 years' worth of research). Unfortunately, several nonstandard techniques and decisions were employed by the author to reduce the original significant effect he found to nonsignificance (Ferguson, 2007).
} 


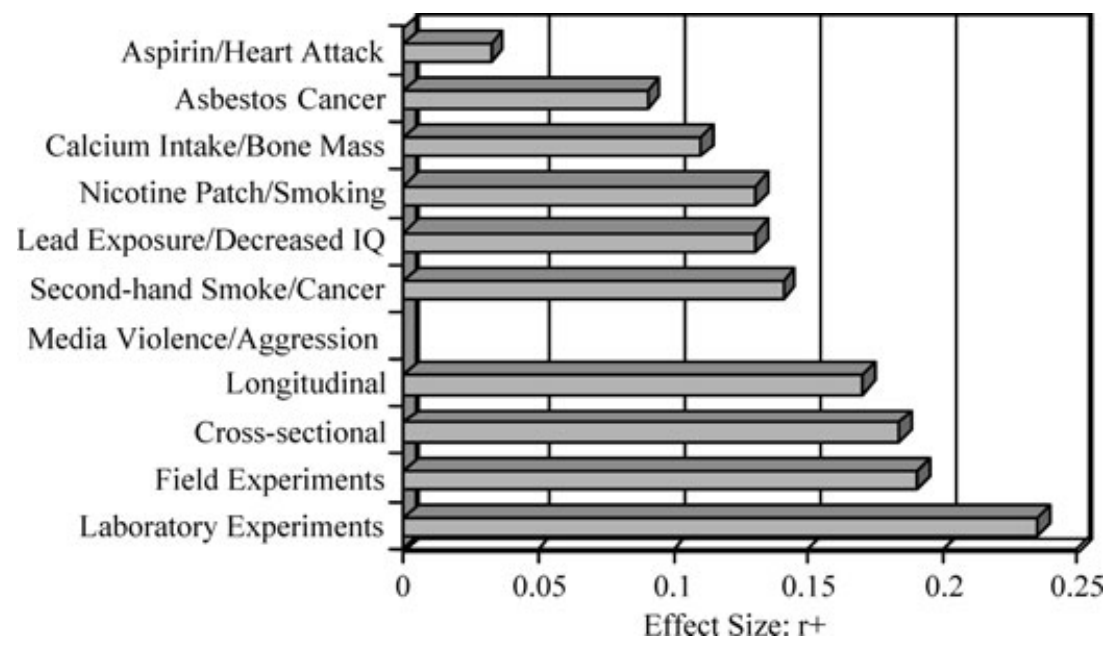

Fig. 1. Comparison of effect sizes of commonly known medical effects to media violence effects. Effect sizes are presented in terms of $r$. Each of these bars is statistically significant, including the bars for each type of study of media violence and aggression. Aspirin/heart attack data from Rosenthal, 1990. Other medical effect sizes from Bushman \& Huesmann, 2001.

convergence of results across several studies of different types. The most recent complete meta-analysis of media violence effects was conducted by Anderson and Bushman (2002a, 2002c). The lower part of Figure 1 displays the average effect size for studies of the relation between media violence exposure and aggressive behavior, separately for each of four types of studies. As can be seen, laboratory experiments, field experiments, cross-sectional correlational studies, and longitudinal studies all yield the same basic effect and one clear conclusion: Violent media exposure increases the likelihood of aggressive behavior. The upper part of Figure 1 shows the effect sizes of other scientifically documented effects, such as the effect of exposure to lead on IQ scores in children, the effect of calcium intake on bone mass, the effect of homework on academic achievement, and the effect of asbestos exposure on cancer. Note that the media violence effect on aggression is larger than each (this will be discussed in more detail later). In other words, the public debate over whether media violence has a causal effect on aggression is over, and should have been over as early as 1975 (Anderson et al., 2003; Bushman \& Anderson, 2001).

Although this conclusion has been reached by many independent government and healthcare organizations, there are several common criticisms of the media violence literature. Some of these criticisms are legitimate and some are not (for details, see Gentile \& Anderson, 2003). Legitimate criticisms include issues such as sample sizes being too small in some empirical studies (which 
makes it harder to detect small but true effects), and some studies claim to study aggressive behavior but do not actually measure aggressive behavior (such as using trait hostility measures or self reports of arguments with spouses-remember, aggression needs to include intent to harm). Illegitimate criticisms include dismissing cross-sectional studies because they cannot "prove" causation (although true at this simplistic level, such studies can support or falsify causal theories), or dismissing experimental studies because they cannot link media violence to serious violent behavior (technically true, but this overlooks the evidence of the external validity of laboratory measures of aggression).

In addition, there are a handful of vocal critics of the media violence literature (e.g., Cumberbatch, 1989; Fowles, 1999; Freedman, 1984, 2002; Jones, 2002), sometimes supported by one or more of the media industries. Interestingly, even the scientists in this group have never published original empirical research on media violence effects in quality peer-reviewed journals, so the basis for their conclusions is unclear. Some of them (e.g., Freedman) are knowledgeable methodologists and are very good at pointing out weaknesses of individual studies. Nonetheless, the critics often make several common errors (for a complete discussion, see Huesmann \& Taylor, 2003). First, they often employ the rhetorical device of assuming that the issue is whether media violence is the "only" (or even primary) cause of aggression, which then allows them to dismiss this issue. No serious researcher makes this claim — aggression is multicausal, and media violence is only one of many risk factors. Second, they often dismiss one type of study altogether, such as dismissing experimental studies because they cannot measure serious real-world violence such as homicide as an outcome variable. Any given study has weaknesses, and most have strengths; it is the total picture from all types of studies that is most informative. Dismissing one methodology yields an incomplete picture. Third, the critics tend to be very critical of studies that show harmful effects of media violence, but very forgiving of studies that fail to show harmful effects. Fourth, the critics tend to analyze studies in a "theoretical vacuum." It is one thing to claim that violent video games do not teach aggression based on the results of one specific empirical study, and quite another to deny everything psychologists and neuroscientists know about how the brain learns. We know that when something is practiced, and especially if it is rewarded contingently, the brain learns. Therefore, it would be absolutely remarkable if people did not learn aggression concepts from playing violent video games.

\section{Circumstances Under Which Media Violence Effects Are Enhanced or Mitigated}

Several factors may enhance or mitigate the effects of media violence exposure (Wilson et al., 1997). Some potential moderating factors are well supported by data whereas others are supported only by popular opinion. Some come directly 
Table 1. Potential Moderators of Media Violence Effects

\begin{tabular}{|c|c|c|}
\hline Moderator & Hypothesis & Research \\
\hline Cognitive cues & $\begin{array}{l}\text { Concepts that are habitually } \\
\text { presented together become linked } \\
\text { in memory, and are used for } \\
\text { interpreting the stimuli. }\end{array}$ & Supported by research \\
\hline Consequences & $\begin{array}{l}\text { The consequences of an aggressive } \\
\text { media act influence future } \\
\text { aggression. An aggressive act } \\
\text { followed by a lack of } \\
\text { consequences, or even a reward, is } \\
\text { more likely to enhance future } \\
\text { aggression than an aggressive act } \\
\text { followed by a punishment. }\end{array}$ & Supported by research \\
\hline Justification & $\begin{array}{l}\text { Media violence presented as justified } \\
\text { is more likely to increase } \\
\text { aggressive behaviors. }\end{array}$ & Supported by research \\
\hline Identification & $\begin{array}{l}\text { The more one identifies and relates to } \\
\text { the aggressor portrayed in violent } \\
\text { media, the greater one's likelihood } \\
\text { of adopting the aggressive } \\
\text { attitudes and behaviors. }\end{array}$ & Supported by research \\
\hline Realism & $\begin{array}{l}\text { The more realistic a portrayed violent } \\
\text { act is, the more likely it is to } \\
\text { influence one's aggression. }\end{array}$ & $\begin{array}{l}\text { Supported by research, although not } \\
\text { as clear as other moderators }\end{array}$ \\
\hline Youth vulnerability & $\begin{array}{l}\text { Younger children are more affected } \\
\text { by media violence than } \\
\text { adolescents or adults. }\end{array}$ & Little empirical support \\
\hline Trait aggression & $\begin{array}{l}\text { Media violence affects only children } \\
\text { who are already high in } \\
\text { aggressiveness. }\end{array}$ & Little empirical support \\
\hline Sex & $\begin{array}{l}\text { Boys are more affected by media } \\
\text { violence than girls. }\end{array}$ & Little empirical support \\
\hline
\end{tabular}

from theories, such as the consequences following an aggressive act, the extent to which one identifies with the aggressor, the meaning associated with elements of a violent scene, or the age of the consumer. We discuss only a few potential moderating factors because of space constraints (Table 1).

\section{Moderators Supported by Data and Theory}

Cognitive Cues. Cognitive Neoassociation theory and the General Aggression Model predict that concepts that are habitually presented together become linked in memory, and help to provide a context within which to interpret stimuli. For example, because guns are frequently paired with violent actions, the mere presence of a gun tends to increase aggression (Berkowitz \& LePage, 1967; 
Carlson, Marcus-Newhall, \& Miller, 1990). However, this effect varies depending on the meaning people attach to the presented weapon. If a weapon (e.g., hunting rifle) is associated with aggressive concepts (e.g., used for killing), then seeing that weapon primes aggressive thoughts and increases the likelihood of aggressive behavior. However, if the same weapon is associated with nonaggressive concepts (e.g., family sport hunting trip), then seeing that weapon does not activate aggressive thoughts and does not increase aggression levels (Bartholow, Anderson, Carnagey, \& Benjamin, 2005).

Consequences. Social Learning Theory and the General Aggression Model predict that seeing what happens after an aggressive media act can change the effect on the viewer of such exposure. An aggressive act followed by a lack of consequences, or even a reward, is more likely to enhance future aggression than an aggressive act followed by a punishment. Most violent media do not show violent acts followed by their appropriate consequences. Instead, most violent acts go unpunished, or even rewarded. Only $19 \%$ of aggressive actors were punished for their aggressive actions in an extensive study of 2,500 hours of U.S. television programs. This study further observed that $8 \%$ of the aggressive actors received both rewards and punishments in the course of events (National Television Violence Study, 1997). Violent video games often provide rewards for practicing aggressive actions in the game. Most violent video games give their characters points, money, status, and higher performance levels for their aggressive actions, and indeed often require the player to play aggressively to advance in the game.

The consequences of an aggressive act are especially important because of their effects on children. Children are more likely to model an observed action that is not punished (Bandura, 1965; Bandura, Ross, \& Ross, 1961, 1963a, 1963b, 1963c). Rewarding a violent act may further enhance the effect; however, this does not mean that observing unrewarded violent acts is safe. In Bandura's classic studies, aggression that was unpunished was copied as much as aggression that was rewarded! In a global context, most media violence is rewarded (Groebel, 1998). The fact that attractive media heroes often use violence to achieve their ends provides three aggression-supporting messages: Aggression is a good means to solve conflicts, it increases one's status, and is exciting (Groebel, 1998).

The extent to which the negative consequences of violent acts are made salient can affect viewers' aggression levels. Violent scenes portrayed with no negative consequences are more likely to enhance viewers' aggression levels than violent scenes that have negative consequences (e.g., remorse, guilt, pain, suffering, and sorrow) (Comstock, 1985). Similarly, violent scenes followed by inaccurate consequences can also enhance viewer's aggression levels (Hogben, 1998). The National Television Violence Study (1997) observed that about half of the violent actions displayed on American television failed to show any suffering or physical injury of the victim. Surprisingly, this rate was even higher for children's 
television, with $62 \%$ of the violent acts showing no negative consequences to the victim (Gunter \& Harrison, 1998).

If the media victim shows pain and suffering, the viewer is less likely to aggress against a real person because pain cues usually inhibit subsequent aggression (Baron, 1971a, 1971b, 1979; Sanders \& Baron, 1975; but see Baron, 1979; Sebastian, 1978, for examples of when pain cues increase aggression). There was no physical outcome of the violence in $76 \%$ of violent scenes and no emotional impact on characters in $90 \%$ of the violent scenes studied in American television (Lichter \& Amundson, 1994).

American media rarely show negative consequences to the perpetrators of violence or to the victims (Dominick, 1973; Potter et al., 1995, Potter \& Ware, 1987; Potter et al., 1997; Smith et al., 1999), but Asian media typically do (Goonasekera $\&$ Kam, 1990). This contextual difference may be one reason why Japanese studies of media violence find weaker effects than American studies (Kodaira, 1998). It is important to note, however, that this is only one of many cultural differences that is likely important (others include Japanese limited access to guns, an emphasis on maintaining personal and familial honor, etc.).

Justification. Another important contextual factor is whether the displayed aggressive acts are portrayed as justified. Media violence presented as justified is more likely to elicit aggressive responses from the viewer (Hogben, 1998). Aggression is often employed in television, films, and video games in the pursuit of an allegedly good cause, as in a deserved punishment for the bad guys. In $44 \%$ of TV shows with violence, the aggressive acts were presented as justified (NTVS, 1997).

Identification. The more one identifies and relates to the aggressor portrayed in violent media, the greater their likelihood of adopting the aggressive attitudes and behaviors. This effect appears to be stronger for children (e.g., Cantor, 1994; Dorr, 1981; Hicks, 1965; Leyens \& Picus, 1973; Paik \& Comstock, 1994; Perry \& Perry, 1976). Longitudinal studies show that children who identify with violent characters have higher aggression levels (Huesmann \& Eron, 1986; Huesmann et al., 2003). People are more likely to identify with the media characters if they appear to be similar, attractive, and heroic (Comstock et al., 1978; Hearold, 1986; Heath, Bresolin, \& Rinaldi, 1989; Lieberman Research, 1975; Liss et al., 1983; Rosekrans \& Hartup, 1967). However, it is important to understand that identification with violent characters is not necessary for media violence effects to occur; aggression levels can be increased even when the viewer does not identify with the violent character.

Realism. The more realistic a portrayed violent act is, the more likely it is to influence one's aggression (Berkowitz \& Alioto, 1973; Feshbach, 1972; 
Geen, 1975). People are more likely to identify with and believe in a realistic portrayal because they can relate their own personal experiences to it. Children who think of violent scenes in the media as representative of real-life score higher on several different aggression measures (Huesmann \& Eron, 1986; Huesmann et al., 2003). Although realism can enhance viewer aggression levels, it also is not necessary-aggression can certainly be enhanced by violent media portrayed with low realism. One problem with "realism" is that it can be defined in multiple ways. Most researchers have focused on the aspect of how realistic/similar to one's life media portrayals are. Note, however, that portrayals that demonstrate the negative consequences are also more "realistic" than those that glamorize violence. Further research is needed to tease apart the various types of realism.

\section{Popular Moderators With Little Empirical Support}

Youth Vulnerability. It has long been assumed that younger children would be more affected by media violence than older children, adolescents, or adults. This assumption is based on theories of children's cognitive development, which suggest that younger children are less cognitively skilled, have a harder time differentiating reality from fantasy, and have less real-life experience against which to compare. However, there is very little evidence that younger children are more vulnerable to media violence effects, and there is some evidence that contradicts the youth vulnerability hypothesis. One meta-analysis seemed to find larger effect sizes for younger children (Paik \& Comstock, 1994), but there are several difficulties with using a meta-analysis to answer this type of question. To truly measure differences in effect sizes across ages, one would need to use the same media violence and the same aggression variables across ages. However, most studies do not show the same types of media violence to children, adolescents, and adults (for some obvious ethical reasons - one could not show a scene from an R-rated movie to children). Furthermore, how people demonstrate aggression changes with age, making it difficult (or impossible) to measure the same type of aggressive behavior at different ages. In one of the few studies to measure different ages with the same stimuli, Anderson et al. (2007; Study 1) had elementary school children and college students play the same children's video games (violent or nonviolent), and perform the same aggression task afterward. Children and adults both were more aggressive after playing the violent children's games, and the effect size was only slightly greater for children. In the absence of strong evidence that age is an important moderating variable, it seems reasonable to hold this theoretically reasonable idea as an open question that needs further study.

However, some related popular ideas can be dismissed. For example, the idea that the ability to distinguish fantasy from reality is a critical moderator of media effects seems intuitively appealing. Yet, to our knowledge, no studies have ever demonstrated this. The most common version of this idea-that people who 
clearly understand that the media violence they consume is fictitious are immune to its effects - is demonstrably false. There are dozens of experimental studies with obviously fictitious violent media as stimuli and college students as participants, and they show the typical media violence effect on aggressive behavior, thought, and feelings. Therefore, the ability to distinguish fantasy from reality clearly does not inoculate one from the harmful effects.

Trait Aggression. It also has been assumed that media violence affects only children who are already high in aggressiveness. This assumption does not come directly from a theoretical analysis, although theories could be adapted to explain it (e.g., aggressive children seek out violent media, which reinforce alreadyexisting schemata and associations). Instead, this assumption is primarily empirically based, originally generated by some early studies of violent television that appeared to find such moderating effects, although there also are some recent studies that demonstrate similar findings (Unsworth, Devilly, \& Ward, 2007). Yet interactions between media violence exposure and trait aggressiveness actually are rare in the literature. Most studies find an effect of media violence on most kids, regardless of trait aggressiveness. For example, in a study of 607 adolescents (Gentile et al., 2004), students who were in the top quartile of personality trait hostility doubled their risk of physical fights if they also played a lot of violent video games, compared to high hostile students who did not play violent games (percentage getting into fights was $63 \%$ compared to $28 \%$, respectively). However, the least hostile students (bottom quartile) were almost 10 times more likely to get into fights if they played violent video games compared to other low hostile students who did not play violent games (38\% and $4 \%$, respectively). Thus, both high- and low-trait aggressive children were affected by the violence in video games to about the same degree (34-35\% increase in absolute percentage terms) or the effect was larger for the low-trait aggressive children (in proportional change, 10 times versus 2 times).

What explains these apparently contradictory findings? One interpretation derives from the fact that studies showing that only the most at-risk children are affected have measured an aggression outcome variable that is either fairly extreme or that requires a threshold to be crossed. For example, if the study has children watch a violent TV show and then looks for fights in the short term, it is likely that only a few of the children would actually get into a fight during the brief observation period after viewing. These few are likely to be those who are already more prone to aggression. This could be interpreted to suggest that only already aggressive children were affected. Yet, it seems more parsimonious to interpret this result (in light of other empirical studies) by assuming that most children were affected, but only those who already were close to the threshold of hitting someone actually showed that behavior. That is, everyone's short-term risk of aggression went up, but fighting behavior was only demonstrated by those with additional 
risk factors for aggression. It is likely that if we chose to measure something less extreme, or earlier in the chain of effects (such as aggressive thoughts or feelings, rather than behaviors) that we would see everyone was affected.

Sex. It also has been assumed that boys are more affected by media violence than girls. This assumption is empirically based on a few studies, not theoretically based. It is difficult to see how the theories could be adapted to explain it. Those empirical studies in which only boys appeared affected are primarily early studies, mostly correlational or longitudinal, where media violence exposure was not manipulated (e.g., Eron et al., 1972; Lefkowitz et al., 1977). More recent studies do not usually find this result. Certainly girls have a lower base rate of physical aggression, and they have a lower base rate of media violence exposure. One plausible explanation is based on a restriction of range problem on media violence exposure for girls in those early studies. But when girls consume high amounts of media violence, they also tend to be more physically aggressive, both in short-term experimental contexts and in longer-term correlational studies (e.g., Anderson et al., 2007; Gentile et al., 2004). Furthermore, some recent research has begun to examine the effects of other types of aggressive behaviors in the media, such as indirect aggression, which is more common for girls. Viewing indirect aggression is associated with both increased indirect aggression during a structured observation and peer reports of indirect aggression in preadolescent girls (Coyne \& Archer, 2004; Coyne, Archer, \& Eslea, 2004; Linder \& Gentile, under review).

\section{Video Games}

Video games may warrant special concern because their effects may be bigger than other forms of media violence. There are several theoretical reasons why this may be (for a more detailed discussion, see Gentile \& Anderson, 2003).

\section{Identification With the Aggressor}

In TV shows and movies there may be several characters with whom an observer can identify, some of whom may not behave in a violent fashion. In violent video games, the player identifies with and takes the role of a violent character. In shooting and fighting games, for instance, the player assumes the identity of the hero or heroine, and then controls that character's actions throughout the game. This commonly includes selection of weapons and target and use of the weapons to wound, maim, or kill the various enemies in the game environment. This character most often is portrayed in a glorified and heroic fashion. 


\section{Active Participation}

Active participation increases learning. The violent video game player is a much more active participant than is the violent TV viewer. Active participation is a more effective teaching tool in part because it requires attention to the material being taught. This attention is very effective in teaching the violent story lines underlying aggressive behavior scripts.

\section{Rehearsal of Entire Aggression Sequence}

Rehearsing an entire behavioral sequence is more effective than rehearsing only a part of it. The aggression script being rehearsed in a video game is more complete than in a TV show or movie. For example, the video game player is given choices on how and when to aggress, and rehearses this choice process throughout the game. The TV viewer, on the other hand, does not have to make any such choices. Virtual reality games involve the participant throwing punches, ducking, and so on. With improved technology, the new consoles (e.g., Nintendo's Wii) are giving players a chance to use the weapon of the game (e.g., swords, guns) to act out and control their game character's actions. As the computer revolution continues, the "realism" of the video game environment will increase dramatically, further increasing the similarity between the rehearsed fictitious aggression sequences in the game and the real-world aggression sequences.

\section{Violence Is Directly Rewarded}

Rewards improve learning. Actually, rewards increase the likelihood of repeating the newly learned behavior, which in turn improves learning. A television viewer is not directly rewarded for aggressive behavior observed in violent TV or movies, whereas a video game player is directly rewarded with points, auditory and visual effects, and progress through game levels.

\section{Repetition Increases Learning}

In a violent video game, the player is required to practice aggressive acts repeatedly throughout the time that one plays, and each game is usually played multiple times. Similarly, the violence rate is much higher in typical shooting and fighting video games than in violent television shows and movies, thus yielding many more repetitions of violent thinking, feeling, and behaving per hour. In sum, there are a number of good theory-based reasons to be especially concerned about video game violence. 


\section{Additional Translation Issues}

Several additional issues are involved in confusions and misunderstandings that frequently occur at the science/public policy interface. We next address the ones that we believe are both common and important.

\section{Causality and Risk Factors}

Despite the plethora of research documenting the effects of media violence, the general public continues to ask: "Does exposure to violent media cause harmful effects?" To answer this question appropriately, it is important to understand how the behavioral and medical sciences determine causality. Modern scientific causality can no longer be understood by thinking of causes as "necessary and sufficient." Causality in modern science is typically probabilistic because most phenomena are influenced by multiple causal factors. No single factor can be considered a "necessary and sufficient" condition for most psychological (or medical) outcomes. For example, some people who do not smoke get lung cancer and not all smokers get lung cancer-these violate the necessary and sufficient conditions for smoking as a cause of lung cancer. Yet, smoking is a causal risk factor for lung cancer because it robustly increases the likelihood of getting cancer, and quitting smoking reduces the risk. Similarly, some people who behave aggressively do not consume media violence and not all people who watch media violence behave aggressively. Yet media violence has been demonstrated to be a causal risk factor for aggression because it robustly increases the likelihood of aggressive thoughts, emotions, and behaviors, and reducing exposure reduces the risk of later aggression (e.g., Robinson et al., 2001).

Simply put, media violence contributes to increased aggression and violence, but it alone is not the sole determinant of such behavior. Other risk factors for aggression include (but are not limited to): prior aggression level, poverty, residing in a violent neighborhood, antisocial peers, and several parental factors (U.S. Department of Health and Human Services, 2001). Violent actions seldom result from a single cause; rather, multiple risk factors converging over time contribute to such behavior.

A risk factor approach to understanding the problem allows one to make sense out of what initially may appear to be contradictory findings. As described earlier, there are some studies demonstrating that only boys or highly aggressive children appeared affected. If we assume that to commit an act of aggression requires that some threshold be passed, some people will be nearer to it at any point in time, by virtue of other risk factors (e.g., being male, history of prior aggression, having been bullied or abused, psychiatric illness). Media violence exposure is likely to increase the risk for most viewers, but will push over the violence threshold only 
those who are closest to the threshold. This is not the same as saying that media violence only affects those at highest risk-it means that it is easiest to see and measure the effect on those at highest risk.

Nonetheless, even holding other risk factors constant, media violence still is significantly related to aggressive behaviors. For example, in a longitudinal study of elementary school children, high violent video game play early in a school year almost doubled the risk of getting into physical fights by later in the school year (increasing the risk from $26 \%$ to $46 \%$; Anderson et al., 2007). However, for children with four additional risk factors at Time 1, the risk of fights increased to $84 \%$ (compared to $16 \%$ for children with no risk factors). Thus, the influence of the mass media is best viewed as one of the many factors that shape numerous behaviors, including aggression.

The probabilistic nature of scientific causality is well accepted in most branches of science. Medical studies suggesting that broccoli may reduce cancer are quickly regarded by many as scientific truths, even though many of these studies are only cross-sectional and the effect sizes are smaller than the effect of media violence on aggression. We do not mean to suggest that such medical studies are unimportant, but exactly the opposite. Studies of media violence often are not regarded as seriously as are purely medical studies (Anderson \& Bushman, 2002b; Potter, 2003), when in fact, both address public health and welfare issues. The media violence domain is often pressured to produce a simple linear necessary and sufficient causal relationship despite the truth that both behavior and physical health are multicausal.

\section{Size of Media Violence Effects}

By conventional statistical interpretations, media violence effects are considered "small" to "moderate" in size (where a correlation of .10 is considered small, .30 is moderate, and .50 is large; Cohen, 1988). Yet, these conventions, which were intended by Cohen to be merely rough guidelines, do not actually fit the data (Hemphill, 2003). Empirically, behavioral scientists rarely find effect sizes of over .30; such effects therefore should be considered "large" rather than "moderate." Humans are complex creatures, and behavior is always multicausal. Using Hemphill's empirical reconceptualization (2003), the media violence effects range from small to large (where .10 is small, .20 is moderate, and .30 is large).

Regardless of which size convention one prefers, it is important to note that the descriptive labels may mislead. For example, Ferguson (2002, p. 447) states that these effect sizes are "small and lack practical significance." Although Ferguson is not alone in making this claim (e.g., Freedman, 2002), it is unclear on what basis it is made. Indeed, it is at odds with empirical comparisons of effect sizes in other public health domains. In contrast to many major medical issues of public 
concern, media violence effects are comparatively greater (see Figure 1). A daily aspirin is effective at reducing the odds of a fatal heart attack, such that this is now a standard prescription for people who have already had a heart attack or are deemed at risk, and tens of thousands of adults have begun taking a daily aspirin even without a physician's recommendation; but, when the effect size is translated into the same scale as is commonly used in the behavioral sciences, we learn that it accounts for less than $1 \%$ of the variance (Hemphill, 2003). Media violence effects are commonly $400 \%$ to $900 \%$ larger. In sum, the media violence effect is as large or larger than the effect of many other risk factors that we as a society have decided are important enough to dedicate significant resources to addressing (e.g., prohibiting lead additives in gasoline and paint, removing asbestos from buildings and brake pads, adding calcium to our daily diet).

The fact that society has not decided how to address the issue of media violence is therefore somewhat paradoxical. It is even more paradoxical when one considers three other important characteristics of media violence. First, unlike many health risk factors, an overwhelmingly large portion of the population (almost everyone, in fact) is exposed to media violence on a daily basis. Second, also unlike most health risk factors, media violence exposure is a relatively simple hazard for individuals to avoid (although it is not simple at the policy level). Third, similar to many other health risk factors, the deleterious effects of exposure to media violence accumulate with repeated exposure.

Even the short-lived effects of a single exposure add significant amounts of aggression to society, because at any given waking hour a large portion of the population either is currently being exposed to violent media or has been exposed to such violence within the past 20 minutes. On a population level, this has important consequences. There are approximately 50 million children in the United States, almost all of whom play video games and watch television (Gentile \& Walsh, 2002). If children's media violence exposure were reduced, there would likely be a tremendous societal impact. If we reduced the exposure for $1 \%$ of children, theoretically that would reduce aggression tendencies of 5,00,000 children.

\section{Why People Seem Unconcerned}

Given the consensus about media violence effects by highly respected and visible organizations, why does it seem that so few people have heard (or are convinced by) the message? For example, when asked if they believe that media violence makes children more aggressive, over half of American parents do (Gentile \& Walsh, 1999), yet only $13 \%$ have any rules in their households regarding the content that is watched (Gentile \& Walsh, 2002). Furthermore, $68 \%$ of American youth (ages 8-18 years) have a television set in their bedrooms, making parental monitoring a difficult if not impossible task (Kaiser Family Foundation, 
2005). In fact, having a TV in the bedroom predicts many negative consequences. Youth with TVs or video games in their bedrooms spend much more time each week watching TV and playing video games, have fewer hobbies and read less, perform more poorly in school, are $31 \%$ more likely to be obese, are less likely to have their media habits monitored by adults, and are less likely to have consistent rules for media use in their households (Dennison, Erb, \& Jenkins, 2002; Gentile \& Walsh, 2002; Kaiser Family Foundation, 2005).

One reason parents do such a poor job of creating a healthy media diet for their children may be the "third person effect." Even though a majority of American parents believe that media violence has negative effects for children in general, they feel that its negative influence on their own kids is much weaker than on others' children (Hoffner \& Buchanan, 2002; Hoffner et al., 1999, 2001). This is the "third-person effect," in which we tend to believe that other people are more influenced by various factors than we or our children are (Davison, 1983; Perloff, 2002). This important barrier to action needs to be overcome for any public policy actions to be broadly effective. To our knowledge, no research has yet addressed how best to overcome it.

However, one aspect that may underlie this thought process may be fairly easy to change. One oft-heard argument is, "I watched lots of these movies and I've never shot anyone." Such reasoning confuses the wide array of media violence effects with only the most extreme form of aggression. Helping parents, educators, and policymakers understand the additive nature of risk and protective factors may help people understand that the effect can exist without necessarily resulting in extreme behaviors (Gentile \& Sesma, 2003). For example, repeated exposure to violent media increases the accessibility of aggressive thoughts, the likelihood of verbal aggression at school, and using physical aggression against one's spouse (e.g., Anderson et al., 2007; Huesmann et al., 2003). It may be easier to get parents to exert more control over their children's media habits if the educational messages focus less on school shootings and more on acts of inappropriate aggression that are fairly common.

A second reason why there may be such a lack of parental action is that they are given a mixed message by the news media about whether they should be concerned. Although scientific research has continued to find stronger support for the causal link over time, the news media have been systematically reporting a weaker link in recent years (Bushman \& Anderson, 2001).

A third reason is that parents also get mixed messages from industry spokespeople themselves. For example, the video game industry representatives often tout what a great rating system they have, but then they turn around and say that there is no evidence that video games could have any harmful effects. The same problem exists in the television and film industries. It is little wonder that the public is confused about how seriously to take the media violence issue. 


\section{Public Policy}

Given that hundreds of studies of all types in many countries have converged on the result that media violence is a contributing cause of aggression, that population exposure to this risk factor is extremely high, and that major policy-focused scientific organizations have concurred that media violence is a serious issue, it is perhaps surprising that so little has been done about it in the policy arena in many countries, especially the United States. One of the primary roles of science in public policy is to provide factual information on important questions concerning public health. Scientists use theories to understand, predict, and interpret the research findings and to answer relevant public policy questions. Unfortunately, nonscientists often do not understand the role of theory in science, and often confuse scientific theories with "guesses," leading to a "my theory is as good as your theory" mentality. Of course, good scientific theories are based on empirical facts and typically have been refined based on many empirical tests. Using current theories, scientists can comment on whether a specific public policy is likely to be successful at achieving a specific result. For example, based on theoretical and corresponding empirical considerations, reducing children's overall exposure to media violence is likely to reduce the overall amount of aggression in a society.

How best to reduce children's exposure to this risk factor is a very different question, of course. Furthermore, scientific data on the moderators of the effects seem particularly useful for public policy formation, as they demonstrate that not all media violence is equally likely to have harmful effects and that some types of people may be more at risk for demonstrating certain types of effects (Table 1). Therefore, policies could be tailored to be focused where they could matter most.

\section{Four Aspects of Public Policy Formation}

Public policy is often created at the intersection of legal issues, political realities, scientific "facts," and personal values (Gentile \& Anderson, 2006). With regard to media violence, U.S. legal issues include concerns about First Amendment rights, as violent speech is protected speech (Winters v. New York, 1948, which found that magazine descriptions and photos of criminal deeds were protected). This does not preclude exploration of a wide array of potential policies including access restrictions, because government restrictions on children's access to pornography have been found consistent with First Amendment concerns. Similarly, violent material, particularly when presented to children, may come within the obscenity exception to the First Amendment (Saunders, 2003a, 2003b). Furthermore, broadcast programming has been granted somewhat reduced First 
Amendment protections, partly because of its accessibility to children (FCC, 2007). As digital media (cable television, video games, the Internet) also become more readily accessible to children, they also may be seen as appropriate domains for reduced First Amendment protections.

The category of political realities includes issues of whether the political willpower exists to champion or implement given policies. Are government restrictions on access likely to be popular with voters? Are the scientific findings likely to influence members of the legislative, executive, and judicial branches into implementing such policies? How hard can legislators be on media industries that spend a lot of money on lobbyists and contribute a lot of money to election campaigns?

The last category, personal values, is especially interesting in shaping public policies. It is quite possible and rational for an individual to understand the adverse effects of a stimulus on society but oppose a potential policy restricting it because such a restriction conflicts with a personal value deemed more important. One parallel example concerns gun control laws. Even if one believes that stricter gun control laws would reduce U.S. homicide rates, one still could oppose such laws rationally simply by placing a greater personal value on easy access to guns than on lower homicide rates.

\section{Public Policy on Media Violence}

In the United States, municipalities, states, and the Federal government all have made some attempts to formulate policies to reduce children's media violence exposure; most such attempts have failed. For example, there have been several laws passed to restrict children's access to violent video games, all of which have been struck down by the courts as infringing on children's First Amendment rights. In most (but not all) of the rulings, the courts failed to see a sufficiently strong causal connection to warrant First Amendment intrusion. This suggests at least four implications relevant to public policy.

First, there is an apparent gap between what the scientific findings suggest and what the U.S. courts and society understand. This is partially due to different conceptions of causality used by scientists and the legal system. Therefore, one implication is to find ways of educating the courts and society about the meaning of causality in science, and how to interpret the empirical data. Lawyers and judges often are asked to make complicated judgments about scientific issues, but they do this without the benefit of having training in those sciences. The courts and bar associations could create specialist trainings-in collaboration with scientists-for lawyers and judges as part of their continuing legal education.

Second, confusion about scientific findings in court is partly due to opposing "expert" testimonies. Because there are no clear rules or guidelines in the public 
domain about what constitutes an expert, it is relatively easy for the entertainment industries to hire "experts" to refute the scientific findings. For example, none of the video game industry "experts" in the cases to date would be considered by the scientific community as real experts on media violence. Furthermore, the common criticisms of media violence research voiced by the industry "experts" have been carefully examined in numerous studies and reviews and found invalid. Nonetheless, many such criticisms sound reasonable to a nonexpert (e.g., judge), and have been taken seriously. Specific criteria could be created to determine who is qualified to speak as an expert in the media violence (or any scientific) domain. As we have noted elsewhere, "We do not claim to have the single best strategy; however, certain qualifications seem absolutely necessary. Expert qualifications should include: (a) doctorate in an appropriate empirical science; (b) multiple publications in top-ranked peer-reviewed journals, based on original empirical data gathered to examine media violence effects; (c) understanding of the strengths and weaknesses of all of the major research designs; and (d) demonstrated willingness and ability to accept and integrate findings from all major research designs" (Anderson \& Gentile, 2008 ). It is worth mentioning that this is not only a policy issue for the legal system, but also for journalists. Under the dictum "get both sides of every story," journalists also often pair an expert (defined as above) against some teenager who just does not like the research, or a parent who allows his or her children to consume violent media, or a media industry representative. Criteria for vetting experts should also be created and taught in journalism schools, to reduce what might be called the "misapplied fairness doctrine" (Bushman \& Anderson, 2001).

Third, researchers must learn that the judicial courts use different standards of causality than most social scientists, and that these standards change depending on the type of legal issue. In particular, if the issue is about regulating access to speech, the U.S. courts are very conservative because speech is at the core of democracy. The courts would be most interested in research demonstrating immediate harm from video games. They are less concerned about cumulative long-term effects than immediate effects. The harm need not be toward others, however-demonstrating harm to the viewing children would also be important. Furthermore, the courts tend to be most interested in studies conducted in real-world contexts, in which most other relevant factors are measured and the study could successfully distinguish the effect of media violence after taking all other factors into account. Currently, because so many factors are known to affect violent behaviors, especially in the immediate context, the courts are less concerned about the long-term independent effects of media violencescientists need to realize that there is a discrepancy between what a social scientist would accept as proof of an effect and what a court would require before it would consider regulating speech. Therefore, researchers who wish to have their research be valuable for public policy debates may need to conduct different 
types of research that will provide the types of answers that courts customarily seek. $^{3}$

This suggests a final implication: perhaps legislators should consider a moratorium on access restriction legislation in the United States for 5-10 years, because such legislation is unlikely to survive First Amendment challenges. Courts rely on precedent, and are unlikely to rule in a different way until enough time has passed for new research to be conducted that would present new evidence. Even if the suggestions mentioned above were immediately adopted, time will be needed for the legal and research professions to change in ways that foster more accurate communication and understanding.

It also may be beneficial to consider the opposite approach. Rather than limiting adult-oriented material, policies could be implemented to increase access to child-appropriate material. This was done most successfully in the United States by the 1996 Telecommunications Act, which set lower boundaries for how many hours (3) of children's educational/informational programming had to be broadcast each week. With the transition to digital television, and the increase in the number of channels that will result from it, these types of issues are even more important now than in the 1990s. Unfortunately, neither the debate on this issue nor potential policy initiatives have reached the broader public's attention. Other similar initiatives that have been considered are reimplementing a definition of family viewing time, during which violent TV shows may not be broadcast (this is often known as a "watershed" policy). In fact, the U.S. Federal Communications Commission recently ruled that Congress could write a law that would allow the FCC to regulate violent content, as it already is able to with sexual content and profanity (FCC, 2007). The report also suggested that Congress could constitutionally put limits on what times excessively violent programming could be aired, as well as suggesting measures the television industry could adopt voluntarily. However, all of these issues deal primarily with broadcast television. The policy arena gets much more complicated when one considers issues of cable television, films, video games, and the Internet; the complications get worse when trying to consider how to craft policy that will be useful after these discrete media converge (when all are digital media and available across media platforms).

Perhaps the most successful set of U.S. public policy initiatives to date have been the Congressional hearings that preceded and motivated the creation of the various media rating systems. The movie, music, video game, and television industries all currently have rating systems (for a review, see Gentile, 2008). Each of these systems was created "voluntarily" after Congressional pressure was

\footnotetext{
${ }^{3}$ Unfortunately, top journals frequently are uninterested in such research because it frequently lacks the "new theoretical developments" so highly prized by those journals. This bias appears even in many "applied" journals. Grant agencies have similarly been reluctant to fund such research because it is not seen as "cutting edge." This is one reason why some in Congress have promoted legislation the specifically targets research funds for such media effects research.
} 
brought to bear on each industry. Perhaps the most interesting of these was the manner in which the television ratings were created. The Telecommunications Act of 1996 mandated that televisions be manufactured with "V-chips" in them. The "V" stands for "violence," although it is a misnomer, as the computer chip is designed to be used by parents to filter several types of content. The television industry was given 1 year to create its own system for rating violent, sexual, and other sensitive content. If the system was not judged to be "acceptable" to the Federal Communications Commission, then the FCC would appoint an advisory committee to create the system (Kunkel, 2003). This approach has been deemed to be constitutional (although no court has been asked to rule on it), and therefore suggests two implications for public policy.

First, the greatest policy benefit of legislators considering laws regarding media violence may be that they heighten awareness of the issue for the public. By providing a public forum for the research to be discussed, and potential solutions to be debated, legislators provide an excellent avenue for helping to translate scientific research into publicly accessible language. Second, as long as the government does not produce the ratings itself (which might violate the First Amendment), there may be a great amount of room for regulating the information that is provided to parents through media ratings. It is possible that regulations could be created directing who produces the ratings (such as an independent organization), the types of information that are provided (such as content information), or the standards of reliability and validity to which ratings should be held.

Unfortunately, there are several serious problems with the U.S. rating systems as they currently exist (for reviews, see Gentile, 2008; Gentile, Humphrey, \& Walsh, 2005). Multiple studies suggest that the various rating systems are neither reliable nor valid. For example, in a study of 1,332 TV shows, across all general audience (not specifically designed for children) shows, $65 \%$ with high-risk violent content did not include the "V" rating, and 80\% with high-risk sexual content did not include the "S" rating (Kunkel et al., 2001). In addition, studies have demonstrated that parents would prefer ratings that are content based, rather than age based (Bushman \& Cantor, 2003; Cantor, 1998a; Cantor, Stutman, \& Duran, 1996; Gentile, 1996). Furthermore, there is some research suggesting that agebased ratings tend to make children more interested in viewing age-inappropriate material, whereas content-based ratings do not have the same level of "forbidden fruit" effect (Bushman \& Cantor, 2003; Cantor, 1998a). Echoing an earlier theme, ratings also tend to be based on what is deemed "offensive" to adults (such as more blood), rather than what types of depictions are actually more harmful to children (such as violence that is not punished). Perhaps most importantly, parents' understanding and use of the various rating systems is poor, which is surprising given that almost all parents say they want ratings (Kunkel et al., 1998).

The issues surrounding ratings is a fertile area for U.S. public policy initiatives, although it remains largely untilled. Perhaps the single most effective policy that 
could be created to help parents manage children's media would be to mandate the creation of one universal rating system that could be used for all media, including TV, movies, video games, and recorded music. Although in the short term parents may feel confused as they attempted to learn a new system, it would reduce confusion in the long term, especially as new media technologies emerge. Furthermore, a universal rating system could take advantage of the wealth of existing research about: what makes a good rating system, what parents want in a rating system, what is most likely to be effective, how to create reliable and valid ratings, how to train raters to rate reliably, and what kinds of content are demonstrably harmful. At the time of this writing, only two countries have created universal ratings, the Netherlands (designed to cover all audiovisual media) and Australia (currently covering films, DVDs, and video games). Nonetheless, several questions would need to be addressed before such a system could be implemented: Who should be rating, and how should they be trained? What should be the specific standards of these rating systems? What strategies should be used to make the general public aware of and understand these ratings? What can make the ratings most effective at helping parents to keep children from viewing inappropriate material? However, these questions are not insurmountable, and in fact are all fairly easily answered with research.

Currently in the United States each industry rates its own products, a fox guarding the henhouse situation. It could be mandated that the ratings be truly independent in some way. The ratings could be provided by an independent ratings board. Or perhaps an independent board would simply train the industry raters to all use the same system, and bring them in for regular reliability testing to ensure that all raters use the system the same way. Or perhaps an independent board would only conduct research on the reliability and validity of the new (or existing) ratings, to ensure that consumers are getting appropriate information. These are not the only options that exist, but it is interesting to note that these policy issues have not been examined seriously even though they may be useful, effective, and constitutional.

Several public policy issues also exist in regard to providing appropriate scientific information about the effects of media on children to the public. Parents need to be actively involved in and aware of their child's media habits. Parents need to monitor and regulate what their child consumes. Simply reducing children's exposure to violent media is a positive step that would yield positive benefits. Parents also need to criticize and comment on the media their children consume. Children were found to have less aggressive attitudes and lower interest in violent programming when parents spoke negatively about violent TV or restricted viewing of violent television content (Nathanson, 1999). As for what is considered adequate media exposure time, the American Academy of Pediatrics recommends that children over age 2 years should not spend more than 1 to 2 hours per day in front of all electronic screens. This includes TV, DVDs, videos, video 
games (handheld, console, or computer), and computers (for nonacademic use). Currently, although the public seems vaguely aware of the issues surrounding media violence, there has been little impact on parental behaviors. In this respect, media violence is similar to other current health issues (e.g., trying to increase physical activity among children to reduce the risk of obesity) and to recent health issues (e.g., tobacco effects on cancer). Great strides are being taken to provide health information to parents and the public in a way that will ultimately improve children's obesity and tobacco outcomes, and similar public policy initiatives could be implemented in the media violence domain.

Several educational interventions have aimed for children to identify the unrealistic consequences of aggressive and violent acts that fail to show the injury and suffering of the victim and of related people. Media literacy programs have been designed to help teach children to understand better what happens when someone gets hurt or killed on TV. In the United States, most of these programs and interventions have been created and run by small nonprofit organizations, such as the National Institute on Media and the Family, Action Coalition for Media Education, and the Media Education Foundation. Because people now receive so much of their information from media, media literacy (the ability to critically consume and create media messages) is an important skill for children. Yet no states in the United States have clearly defined and incorporated media literacy standards into their educational curriculum, although several (e.g., New Mexico, Iowa) have some mention of it in their codes. Helpful policy initiatives could be instituted at the school, district, state, or federal levels for implementing a set of media literacy standards for children.

In the United States, most considerations of public policy about children's media focus primarily on the Federal level. However, there are several other levels at which policy initiatives could be fruitfully explored. For example, the national or state chapters of the American Academy of Pediatrics could create policies that require pediatricians to provide parents with information about media effects during well-child visits. Medical schools or the American Medical Association could require that all medical students have 4 hours of training on media effects during their pediatrics rotations. States could create policies about how much or what kinds of media are allowed in state-licensed daycares. Hospitals could incorporate information about media effects into their prenatal birth classes. States or cities could incorporate media effects information into parenting classes, such as those provided to new parents or to divorcing parents. States could require that all workers in programs such as Women with Infants and Children (WIC) or other relevant department of health workers be trained, and given materials to provide to the parents they serve.

Although the majority of literature discussed here is from the United States, the general issues raised here are faced by every nation. The attempt to have productive public policy debates is often mischaracterized as a rush to censorship. 
It is important to note that this characterization is an attempt to discredit the research and to derail debate. It is even more important, however, to note that almost no country in the world advocates censorship as a solution to the problem (FrauMeigs, 2003). Instead, a growing number of countries are discussing and implementing policies in a manner that is becoming known as "co-regulation" (Aroldi, 2003; Barnard, 2003; Palzer \& Scheuer, 2003; Shipard, 2003). Co-regulation can be defined as incorporating both public (government) regulation and selfregulation in a combined and cooperative manner. Although there is not space here to describe all of the potential aspects of such an approach, some examples may be useful (for a discussion of co-regulation, see Palzer \& Scheuer, 2003).

In a study of six European Union countries (Italy, France, Germany, Netherlands, Spain, and Sweden), co-regulatory mechanisms for broadcast media were judged to have three phases, regulation, self-regulation, and control (Aroldi, 2003). The forms of each varied from country to country, but shared some principles.

- Regulation served to define the principles involved in protecting minors, defining the criteria for classification of media, and to nominate the instruments of control. These included defining standards for ratings or codes of conduct, which were often tied to broadcasting licensure or accreditation of broadcasters by government authorities.

- Self-regulation took many forms, including the standardization and creation of a universal rating system administered by a "third" certifying body (created partly through an association of broadcasters and media producers) or the adoption of watershed viewing times by broadcasters.

- Control included various forms, some independent and some cooperative, aiming to verify the activity of self-regulation by broadcasters. These included self-monitoring, a posteriori control by government regulators, a posteriori control by designated third parties, and post hoc investigations based on public complaints.

Aroldi (2003) suggests that across several European countries, two models tend to be used that converge on a co-regulatory broadcasting model. These are (1) the watershed model in which certain types of programming are restricted to specific hours, and (2) media ratings that provide content information and age guidelines. Even if these are instituted carefully, they are not without problems. For example, the watershed model is predicated on the assumption that children are not likely to be watching television after certain hours. However, in the United States the number of children aged 2 to 11 years watching TV does drop at $9 \mathrm{pm}$, but only from 12 million to 10.8 million children (Potter, 2003). Even at $11 \mathrm{pm}$ there are still 3.2 million children watching. Several problems with the functionality of rating systems have already been discussed, but they too are predicated on the 
assumption that parents are present to use them at the time children are turning on the TV.

There are obviously no "one size fits all" policy options across nations. Countries vary widely on constitutional issues, approaches to licensing and supervision of broadcasting, public versus private control, etc. (Hoffmann-Riem, 1996). Nonetheless, all countries face similar issues, and two trends will only increase the similarity in the future: These are media globalization and media convergence. In the past, several of the issues of concern about media effects could be dismissed as being largely a U.S. problem. Even if this was once true, it is no longer. The media are dominated by huge multinational corporations. American media are available in almost every nation in the world, and other nations' media are available in the United States. The deregulation of media in many countries has helped to make this rich diversity possible, but it also makes the need for good policy more important (McChesney, 2002). The second trend is that once-discrete media are merging. The "digital revolution" has already blurred the lines between various media. One can already watch TV shows on cable, on DVD, on computers, on hand-held video game players (e.g., PSP), and on one's mobile telephone. Policies regarding licensing and supervision are going to be challenged to keep up with technology, as will the definitions of broadcasting and mass media.

There are, however, some promising multinational approaches that may provide a foundation for national policy efforts (von Feilitzen \& Carlsson, 1999), two of which are particularly instructive. The United Nations Convention on the Rights of the Child is an international treaty recognizing the human rights of children, with 192 countries ratifying it (the United States and Somalia being exceptions). The Convention is a comprehensive document created by the consensus of nations over a 10-year period (see http://www.unicef.org/crc/ for a detailed description). Several of its provisions are relevant to media policy. Articles 12, 13, 16, and 18 discuss freedom of access to information, freedom of expression, privacy, and the parents' primary responsibility for children's healthy development. Article 17 specifically discusses mass media in this context, encouraging educational media, children's books, regard for indigenous cultures, and encouraging "the development of appropriate guidelines for the protection of the child from information and material injurious to his or her well-being." The Convention therefore provides a foundation for creating and evaluating media policies regarding children, although countries may implement the Convention in whatever way is most appropriate for each (Hammarberg, 1998).

The European directive "Television without Frontiers" and its later modifications have also provided a multinational set of guidelines for children's media, and these affect all European Union nations. The directive focuses on two areas of media policy for the protection of minors: advertising to children and television programming. In particular, Article 1 of Directive 97/36/EC directs that member states take "appropriate measures to ensure that television broadcasts" 
do not include programs that are "likely to impair the physical, mental, or moral development of minors, except where it is ensured, by selecting the time of the broadcast or by any technical measure, that minors in the area of transmission will not normally hear or see such broadcasts" (Aroldi, 2003, p. 183). Again, a common framework is provided, but specific policies are left to individual nations. These multinational approaches may hold great promise for public policy discussions. It is worth noting that both approaches reject a priori censorship.

In summary, there is ample scientific evidence demonstrating that exposure to media violence increases the risk of aggressive behavior. Parents and policymakers have been rightly concerned about it, although not always for the right reasons. However, the media industries profit from it, and parents and policymakers receive mixed messages about the effects despite the fact that prominent independent public health and government agencies have concluded that the effect is real and sufficiently large to warrant action. The effects are likely to become greater over time, as different media converge, become more interactive, become more global, and colonize more spaces in our lives. This is an issue for which many potentially efficacious public policy options exist, yet too few have been seriously considered. We hope that will be rectified in the coming years.

\section{References}

Anderson, C. A. (1989). Temperature and aggression: Ubiquitous effects of heat on the occurrence of human violence. Psychological Bulletin, 106, 74-96.

Anderson, C. A., Anderson, K. B., Dorr, N., DeNeve, K. M., \& Flanagan, M. (2000). Temperature and aggression. Advances in Experimental Social Psychology, 32, 63-133. New York: Academic Press.

Anderson, C. A., Berkowitz, L., Donnerstein, E., Huesmann, L. R., Johnson, J., Linz, D., \& Anderson, C. A. (1989). Temperature and aggression: Ubiquitous effects of heat on the occurrence of human violence. Psychological Bulletin, 106, 74-96.

Anderson, C. A., Berkowitz, L., Donnerstein, E., Huesmann, L. R., Johnson, J., Linz, D., Malamuth, N., \& Wartella, E. (2003). The influence of media violence on youth. Psychological Science in the Public Interest, 4, 81-110.

Anderson, C. A., \& Bushman, B. J. (1997). External validity of "trivial" experiments: The case of laboratory aggression. Review of General Psychology, 1, 19-41.

Anderson, C. A., \& Bushman, B. J. (2001). Effects of violent video games on aggressive behavior, aggressive cognition, aggressive affect, physiological arousal, and prosocial behavior: A metaanalytic review of the scientific literature. Psychological Science, 12, 353-359.

Anderson, C. A., \& Bushman, B. J. (2002a). The effects of media violence on society. Science, 295, $2377-2378$.

Anderson, C. A., \& Bushman, B. J. (2002b). Human aggression. Annual Review of Psychology, 53, $27-51$.

Anderson, C. A., \& Dill, K. E. (2000). Video games and aggressive thoughts, feelings, and behavior in the laboratory and in life. Journal of Personality and Social Psychology, 78, 772-790.

Anderson, C. A., \& Gentile, D. A. (2008). Media violence, aggression, and public policy. In E. Borgida \& S. T. Fiske (Eds). Beyond common sense: Psychological Science in the courtroom. (pp. 281-300). Malden, MA: Blackwell Publishing.

Anderson, C. A., Gentile, D. A., \& Buckley, K. E. (2007). Violent Video game effects on children and adolescents: Theory, research, and public policy. New York: Oxford University Press. 
Anderson, C. A., \& Huesmann, L. R. (2003). Human aggression: A social-cognitive view. In M. A. Hogg \& J. Cooper (Eds.), Handbook of social psychology (pp. 296-323). London: Sage Publications.

Anderson, C. A., Lindsay, J. J., \& Bushman, B. J. (1999). Research in the psychological laboratory: Truth or triviality? Current Directions in Psychological Science, 8, 3-9.

Anderson, C. A., Sakamoto, A., Shibuya, A., Swing, E., Engelberth, N., Ihori, N., Saleem, M., \& Barlett, C. (under review). Violent video game effects on aggression in Japan and Western Countries.

Anderson, V. L. \& McLean, R. A. (1974). Design of experiments: A realistic approach. New York: Dekker.

Aroldi, P. (2003). Television and protection of minors in some European countries: A comparative study. In U. Carlsson \& C. von Feilitzen (Eds.), Promote or protect? Perspectives on media literacy and media regulations (pp. 179-196). Göteborg, Sweden: The UNESCO International Clearninghouse on Children and Violence on the Screen.

Australian College of Paediatrics. (1994). Policy statement. Children's television. Journal of Paediatrics \& Child Health, 30(1), 6-8.

Bachrach, R. (1986). The differential effect of observation of violence on kibbutz and city children in Israel. In L. R. Huesmann \& L. D. Eron (Eds.), Television and the aggressive child: A cross-national comparison (pp. 210-238). Hillsdale, NJ: Lawrence Erlbaum Associates.

Bandura, A. (1965). Influence of models' reinforcement contingencies on the acquisition of imitative responses. Journal of Personality and Social Psychology, 1, 589-595.

Bandura, A., Ross, D., \& Ross, S. A. (1961). Transmission of aggression through imitation of aggressive models. Journal of Abnormal and Social Psychology, 63, 575-582.

Bandura, A., Ross, D., \& Ross, S. A. (1963a). A comparative test of the status envy, social power, and secondary reinforcement theories of identificatory learning. Journal of Abnormal and Social Psychology, 67, 527-534.

Bandura, A., Ross, D., \& Ross, S. A. (1963b). Imitation of film-mediated aggressive models. Journal of Abnormal and Social Psychology, 66, 3-11.

Bandura, A., Ross, D., \& Ross, S. A. (1963c). Vicarious reinforcement and imitative learning. Journal of Abnormal and Social Psychology, 67, 601-607.

Barnard, M. (2003). Internet content regulation in Australia: A co-regulatory approach. In U. Carlsson \& C. von Feilitzen (Eds.), Promote or Protect? Perspectives on media literacy and media regulations (pp. 243-248). Göteborg, Sweden: The UNESCO International Clearninghouse on Children and Violence on the Screen.

Baron, R. A. (1971a). Aggression as a function of magnitude of victim's pain cues, level of prior anger arousal, and aggressor-victim similarity. Journal of Personality and Social Psychology, $18,48-54$.

Baron, R. A. (1971b). Magnitude of victim's pain cues and level of prior anger arousal as determinants of adult aggressive behavior. Journal of Personality and Social Psychology, 17, 236243.

Baron, R. A. (1979). Effects of victim's pain cues, victim's race, and level of prior instigation upon physical aggression. Journal of Applied Social Psychology, 9, 103-114.

Baron, R. A., \& Richardson, D. R. (1994). Human aggression (2nd ed.). New York: Plenum.

Bartholow, B. D., Anderson, C. A., Carnagey, N. L., \& Benjamin, A. J. (2005). Interactive effects of life experience and situational cues on aggression: The weapons priming effect in hunters and nonhunters. Journal of Experimental Social Psychology, 41, 48-60.

Berkowitz, L. (1984). Some effects of thoughts on the anti- and prosocial influences of media events: A cognitive neoassociationistic analysis. Psychological Bulletin, 95, 410-427.

Berkowitz, L. (1989). Frustration-aggression hypothesis: Examination and reformulation. Psychological Bulletin, 106, 59-73.

Berkowitz, L. (1993). Aggression: Its causes, consequences, and control. New York: McGraw-Hill.

Berkowitz, L., \& Alioto, J. T. (1973). The meaning of an observed event as a determinant of its aggressive consequences. Journal of Personality and Social Psychology, 28, 206-217.

Berkowitz, L., \& LePage, A. (1967). Weapons as aggression-eliciting stimuli. Journal of Personality and Social Psychology, 7, 202-207. 
Bjorkqvist, K., Osterman, K., \& Kaukiainen, A. (1992). The development of direct and indirect aggressive strategies in males and females. In K. Bjokqvist \& P. Niemela (Eds.), Of mice and women: Aspects of female aggression. San Diego, CA: Academic Press.

Bushman, B. J. (1995). Moderating role of trait aggressiveness in the effects of violent media on aggression. Journal of Personality and Social Psychology, 69, 950-960.

Bushman, B. J., \& Anderson, C. A. (1998). Methodology in the study of aggression: Integrating experimental and nonexperimental findings. In R. Geen \& E. Donnerstein (Eds.) Human aggression: Theories, research, and implications for social policy (pp. 23-48). San Diego, CA: Academic Press. (Note: In the original published version, the publisher inadvertently switched several figures between different articles. For a PDF of the corrected version, go to: http://www.psychology.iastate.edu/faculty/caa/recpub.html)

Bushman, B. J., \& Anderson, C. A. (2001). Media violence and the American public: Scientific facts versus media misinformation. American Psychologist, 56, 477-489.

Bushman, B. J., \& Anderson, C. A. (2002). Violent video games and hostile expectations: A test of the general aggression model. Personality and Social Psychology Bulletin, 28, 16791686.

Bushman, B. J., \& Cantor, J. (2003). Media ratings for violence and sex: Implications for policymakers and parents. American Psychologist, 58, 130-141.

Bushman, B. J., \& Huesmann, L. R. (2001). Effects of televised violence on aggression. In D. Singer \& J. Singer (Eds.), Handbook of children and the media (pp. 223-254). Thousand Oaks, CA: Sage Publications.

Buss, A. H. (1961). The psychology of aggression. New York: John Wiley.

Cantor, J. (1994). Fright reactions to mass media. In J. Bryant \& D. Zillmann (Eds.), Media effects: Advances in theory and research (pp. 213-245). Hillsdale, NJ: Erlbaum.

Cantor, J. (1998a). Children's attraction to violent television programming. In J. H. Goldstein (Ed.), Why we watch: The attractions of violent entertainment (pp. 88-115). New York: Oxford University Press.

Cantor, J. (2003, May). "I'll never have a clown in my house": Frightening movies and enduring emotional memory. Paper accepted for presentation at the Annual Conference of the International Communication Association. San Diego.

Cantor, J., Stutman, S., \& Duran, V. (1996, November 21). What parents want in a television rating system: Results of a national survey [Report released by the National PTA, the Institute for Mental Health Initiatives, and the University of Wisconsin-Madison]. Retrieved August 23, 2006, from http://www.pta.org/ptacommunity/tvreport.asp

Carll, E., Singer, D., Anderson, C., Bushman, B., Dill, K., \& Friedland, L. (2005). American Psychological Association Resolution on Violence in Video Games and Interactive Media, adopted by APA on August 17, 2005. (Can be downloaded from: http://www.psychology. iastate.edu/faculty/caa/abstracts/2005-2009/05APA.pdf).

Carlsmith, J. M., Ellsworth, P. C., \& Aronson, E. (1976). Methods of research in social psychology. Menlo Park, CA: Addison-Wesley.

Carlson, M., Marcus-Newhall, A., \& Miller, N. (1989). Evidence for a general construct of aggression. Personality and Social Psychology Bulletin, 15, 377-389.

Carlson, M., Marcus-Newhall, A., \& Miller, N. (1990). Effects of situational aggression cues: A quantitative review. Journal of Personality and Social Psychology, 58, 622-633.

Carnagey, N. L., \& Anderson, C. A. (2003). Theory in the study of media violence: The general aggression model. In D. A. Gentile (Ed.), Media violence and children: A complete guide for parents and professionals (pp. 87-106). Westport, CT: Praeger.

Carnagey, N., \& Anderson, C. (2004). Violent video game exposure and aggression: A literature review. Minerva Psichiatrica, 45, 1-18.

Carnagey, N. L., Anderson, C. A., \& Bushman, B. J. (2007). The effect of video game violence on physiological desensitization to real-life violence. Journal of Experimental Social Psychology, $43,489-496$.

Chaffee, S. H. (1972). Television and adolescent aggressiveness (overview). In G. A. Comstock \& E. A. Rubinstein (Eds.), Television and social behavior: A technical report to the Surgeon General's Scientific Advisory Committee on Television and Social Behavior: Vol. 3. Television 
and adolescent aggressiveness (DHEW Publication No. HSM 72-9058, pp. 1-34). Washington, DC: U.S. Government Printing Office.

CIRP (1998, 2005). Cooperative Institutional Research Program survey results. Ames, IA: Office of Institutional Research.

Cohen, J. (1988). Statistical power analysis for the behavioral sciences (2nd ed.). Hillsdale, NJ: Lawrence Earlbaum Associates.

Comstock, G. (1980). New emphases in research on the effects of television and film violence. In E. L. Palmer \& A. Dorr (Eds.), Children and the faces of television: Teaching, violence, selling (pp. 129-148). New York: Academic Press.

Comstock, G. A. (1985). Television and film violence. In S. Apter \& A. Goldstein (Eds.), Youth violence: Programs and prospects. New York: Perhamon.

Comstock, G. A., Chaffee, S., Katzman, N., McCombs, M., \& Roberts, D. (1978). Television and social behavior. New York: Columbia University Press.

Comstock, G., \& Scharrer, E. (2003). Meta-analyzing the controversy over television violence and aggression. In D. A. Gentile (Ed.), Media violence and children (pp. 205-226). Westport, CT: Praeger Publishers.

Coyne, S. M., \& Archer, J. (2004). The relationship between indirect and physical aggression on television and in real life. Social Development, 14, 324-338.

Coyne, S. M., Archer, J., \& Eslea, M. (2004). Cruel intentions on television and in real life: Can viewing indirect aggression increase viewers' subsequent indirect aggression? Journal of Experimental Child Psychology, 88, 234-253.

Crick, N. R., \& Grotpeter, J. K. (1995). Relational aggression, gender, and social-psychological adjustment. Child Development, 66, 710-722.

Cumberbatch, G. (1989). A measures of uncertainty: The effects of the mass media. London: John Libbey.

Davison, W. P. (1983). The third-person effect in communication. Public Opinion Quarterly, 47, 1-15.

Dennison, B. A., Erb, T. A., \& Jenkins, P. L. (2002). Television viewing and television in bedroom associated with overweight risk among low-income preschool children. Pediatrics, 109, 10281035.

Dominick, J. R. (1973). Crime and law enforcement on prime-time television. Public Opinion Quarterly, 37, 241-250.

Donnerstein, E., \& Berkowitz, L. (1981). Victim reactions in aggressive erotic films as a factor in violence against women. Journal of Personality and Social Psychology, 41, 710724.

Dorr, A. (1981). Television and affective development and functioning: Maybe this decade. Journal of Broadcasting, 25(4), 335-345.

Entertainment Software Association. (2006). Essential facts about games and youth violence. Available: http://www.theesa.com/archives/2006EF\%20Youth\%20Violence.pdf. Accessed May 15, 2007.

Eron, L. D., Gentry, J. H., \& Schlegel, P. (1994). Reason to hope: A. psychosocial perspective on violence and youth. Washington, DC: American Psychological Association Press.

Eron, L. D., Huesmann, L. R., Lefkowitz, M. M., \& Walder, L. O. (1972). Does television violence cause aggression? American Psychologist, 27, 253-263.

Eysenck, H. J., \& Nias, D. K. B. (1978). Sex, violence, and the media. New York: Saint Martin's Press.

Federal Communications Commission. (2007, April 15). In the Matter of Violent Television Programming and Its Impact on Children. MB Docket No., 04-261. Page 14.

Ferguson, C. J. (2002). Media violence: Miscast causality. American Psychologist, 57(6-7), 446-447.

Ferguson, C. J. (2007). Evidence for publication bias in video game violence effects literature: A meta-analytic review. Aggression and Violent Behavior, 12, 470-482.

Feshbach, S. (1972). Reality and fantasy in filmed violence. In G. A. Comstock \& E. A. Rubinstein (Eds.), Television and social behavior: A technical report to the Surgeon General's Scientific Advisory Committee on Television and Social Behavior: Vol. 3. Television and adolescent aggressiveness (DHEW Publication No. HSM 72-9058, pp. 318-345). Washington, DC: U.S. Government Printing Office.

Fowles, J. (1999). The case for television violence. Thousand Oaks, CA: Sage Publications. 
Frau-Meigs, D. (2003). Media Regulation, Self-regulation and Education. In C. von Feilitzen and U. Carlsson (Eds). Promote or protect? Perspectives on Media Literacy and Media Regulations (pp. 23-40). International Clearinghouse on Children and Violence on the Screen, Goteborg University, Sweden.

Freedman, J. (1984). Effects of television violence on aggressiveness. Psychological Bulletin, 96, $227-246$.

Freedman, J. L. (2002). Media violence and its effects on aggression: Assessing the scientific evidence. Toronto: University of Toronto Press.

Geen, R. G. (1975). The meaning of observed violence: Real vs. fictional violence and consequent effects on aggression and emotional arousal. Journal of Research in Personality, 9, 270-281.

Geen, R. G. (2001). Human aggression (2nd ed.). Philadelphia: Open University Press.

Geen, R. G., \& Thomas, S. L. (1986). The immediate effects of media violence on behavior. Journal of Social Issues, 42(3), 7-27.

Gentile, D. A. (1996). National survey of parent media attitudes, behaviors, and opinions. Minneapolis, MN: National Institute on Media and the Family.

Gentile, D. A. (Ed.) (2003). Media violence and children. Westport, CT: Praeger.

Gentile, D. A. (2008). The rating systems for media products. In S. L. Calvert \& B. J Wilson (Eds). Blackwell handbook of child development and the media. Malden, MA: Blackwell Publishing.

Gentile, D. A., \& Anderson, C. A. (2003). Violent video games: The Newest Media Violence Hazard. Chapter in D. A. Gentile (Ed.) Media violence and children. Westport, CT: Praeger.

Gentile, D. A., \& Anderson, C. A. (2006). Violent video games: Effects on youth and public policy implications. Chapter in N. Dowd, D. G. Singer, \& R. F. Wilson (Eds.), Handbook of children, culture, and violence (pp. 225-246). Thousand Oaks, CA: Sage.

Gentile, D. A., Humphrey, J., \& Walsh, D. A. (2005). Media ratings for movies, music, video games, $\&$ television: A review of the research and recommendations for improvements. Adolescent Medicine Clinics, 16, 427-446.

Gentile, D. A., Lynch, P. L., Linder, J. R., \& Walsh, D. A. (2004). The effects of violent video game habits on adolescent hostility, aggressive behaviors, and school performance. Journal of Adolescence, 27, 5-22.

Gentile, D. A., \& Sesma, A. (2003). Developmental approaches to understanding media effects on individuals. In D. A. Gentile (Ed.), Media violence and children. Westport, CT: Greenwood Publishing.

Gentile, D. A., \& Walsh, D. A. (1999). National survey of family media habits, knowledge, and attitudes. Minneapolis, MN: National Institute on Media and the Family.

Gentile, D. A., \& Walsh, D. A. (2002). A normative study of family media habits. Applied Developmental Psychology, 23, 257-178.

Goonasekera, A., \& Kam, L. Y. (1990). Violence on television in Asia. Asian Journal of Communication, 1, 137-146.

Goonasekera, A., \& Lock, Y. K. (1990). Violence on television in Asia. Asian Journal of Communication, 1(1), 136-146.

Groebel, J. (1998). The UNESCO global study on media violence: A joint project of UNESCO, the World Organization of the Scout Movement and Utrecht University, The Netherlands. Report presented to the Director General of UNESCO, UNESCO, Paris.

Gunter, B., \& Harrison, J. (1998). Violence on television in Britain: An analysis of amount, nature, location and origin of violence in programmes. London: Routledge.

Hammarberg, T. (1998). The child and the media. A report from the un committee on the rights of the child. U Carlsson Ulla \& Cecilia von Feilitzen (ur.), Children and media violence (str. 31-34). The UNESCO International Clearinghouse on Children and Violence on the Screen.

Hearold, S. (1986). A synthesis of 1043 effects of television on social behavior. In G. Comstock (Ed.), Public communication and behavior (Vol. 1, pp. 65-133). New York: Academic Press.

Heath, L., Bresolin, L. B., \& Rinaldi, R. C. (1989). Effects of media violence on children. Archives of General Psychiatry, 46, 376-379.

Hemphill, J. F. (2003). Interpreting the magnitudes of correlation coefficients. American Psychologist, $58,78-79$. 
Hicks, D. J. (1965). Imitation and retention of film-mediated aggressive peer and adult models. Journal of Personality and Social Psychology, 2, 97-100.

Hoffmann-Riem, W. (1996). Regulating media. New York: The Guildford Press.

Hoffner, C., \& Buchanan, M. (2002). Parents' responses to television violence: The third-person perception, parental mediation and support for censorship. Media Psychology, 4, 231-252.

Hoffner, C., Buchanan, M., Anderson, J. D., Hubbs, L. A., Kamigaki, S. K., Kowalczyk, L., Pastorek, A., Plotkin, R. S., \& Silberg, K. J. (1999). Support for censorship of television violence: The role of the third-person effect and news exposure. Communication Research, 26, 726-742.

Hoffner, C., Plotkin, R. S., Buchanan, M., Anderson, J. D., Kamigaki, S. K., Hubbs, L. A., Kowalczyk, L., Silberg, K. J., \& Pastorek, A. (2001). The third-person effect in perceptions of the influence of television violence. Journal of Communication, 51, 283-299.

Hogben, M. (1998). Factors moderating the effect of television aggression on viewer behavior. Communication Research, 25, 220-247.

Howitt, D., \& Cumberbatch, G. (1975). Mass media violence and society. New York: John Wiley.

Huesmann, L. R. (1997). Observational learning of violent behavior. In A. Raine, P. A. Brennen, D. P. Farrington, \& S. A. Mednick (Eds.), Biosocial bases of violence (pp. 69-88). New York: Plenum Press.

Huesmann, L. R. (1998). The role of social information processing and cognitive schema in the acquisition and maintenance of habitual aggressive behavior. In R. G. Geen \& E. Donnerstein (Eds.), Human aggression: Theories, research, and implications for social policy (pp. 73-109). New York: Academic Press.

Huesmann, L. R., \& Eron, L. D. (Eds.). (1986). Television and the aggressive child: A cross-national comparison. Hillsdale, NJ: Erlbaum.

Huesmann, L. R., Lagerspetz, K., \& Eron, L. D. (1984). Intervening variables in the TV violenceaggression relation: Evidence from two countries. Developmental Psychology, 20, 746-775.

Huesmann, L. R., \& Miller, L. S. (1994). Long-term effects of repeated exposure to media violence in childhood. In L. R. Huesmann (Ed.), Aggressive behavior: Current perspectives (pp. 153-183). New York: Plenum Press.

Huesmann, L. R., Moise, J. F., \& Podolski, C. L. (1997). The effects of media violence on the development of antisocial behavior. In D. Stoff, J. Breling \& Master (Eds.) Handbook of Antisocial Behavior (pp. 181-193). New York: John Wiley \& Sons.

Huesmann, L. R., Moise-Titus, J., Podolski, C. L., \& Eron, L. (2003). Longitudinal relations between children's exposure to TV violence and their aggressive and violent behavior in young adulthood: 1977-1992. Developmental Psychology, 39, 201-221.

Huesmann, L. R., \& Taylor, L. D. (2003). The case against the case against media violence. In D. A. Gentile (Ed.), Media violence and children (pp. 107-130). Westport, CT: Praeger.

Huston, A. C., Donnerstein, E., Fairchild, H., Feshbach, N. D., Katz, P. A., Murray, J. P., Rubinstein, E. A., Wilcox, B. L., \& Zuckernan, D. (1992). Big world. small screen: The role of television in American Society. Lincoln: University of Nebraska Press.

Joint Statement. (2000). Joint statement on the impact of entertainment violence on children. Retrieved December 2, 2003, from http://www.aap.org/advocacy/releases/jstmtevc.htm

Jones, G. (2002). Killing monsters: Why children needfantasy, super heroes, and make-believe violence. New York: Basic Books.

Kaiser Family Foundation. (2005, March). Generation M: Media in the lives of eight to eighteen year olds. Available online at: http://www.kff.org/entmedia/entmedia030905pkg.cfm (last accessed August 2007).

Kefauver, E. (1954). U.S. Congress, Juvenile Delinquency (Television Programs), 1954.

Kodaira, S. I. (1998). A review of research on media violence in Japan. In U. Carlsson \& C. von Feilitzen. (Eds.) Children and media violence. The UNESCO International Clearinghouse on Children and Violence on the Screen. Göteborg, pp. 81-105.

Kunkel, D. (2003). The road to the V-chip: Television violence and public policy. In D. A. Gentile. (Ed.), Media violence and children: A complete guide for parents and professionals (pp. 227-246). Westport, CT: Praeger.

Kunkel, D., Farinola, W. J. M., Cope, K. M., Donnerstein, E., Biely, E., \& Zwarun, L. (1998). Rating the TV ratings: An assessment of the television industry's use of V-chip ratings. Menlo Park, CA: Kaiser Family Foundation. 
Kunkel, D., Farinola, W. J. M., Cope, K. M., Donnerstein, E., Biely, E., Zwarun, L., \& Rollin, E. (2001). Assessing the validity of V-chip rating judgments: The labeling of high-risk programs. In B. Greenberg (Ed), The alphabet soup of television program ratings (pp. 51-68). Cresskill, NJ: Hampton Press.

Lagerspetz, K. M., \& Bjorkqvist, K. (1992). Indirect Aggression in Girls and Boys. In L. R. Huesmann. (Ed.), Aggressive behavior: Current perspectives (pp. 131-50). New York: Plenum.

Lagerspetz, K. M. J., Bjorkqvist, K., \& Peltonen, T. (1988). Is indirect aggression typical of females? Gender differences in aggressiveness in 11- to 12-year-old children. Aggressive Behavior, 14, 403-414.

Lefkowitz, M. M., Eron, L. D., Walder, L. O., \& Huesmann, L. R. (1977). Growing up to be violent: A longitudinal study of the development of aggression. New York: Pergamon Press.

Lemish, D. (1998). Fighting Against Television Violence. An Israeli Case Study. In U. Carlsson \& C. von Feilitzen (Eds). Children and Media Violence. Goteborg, Sweden: UNESCO International Clearinghouse on Children and Violence on the Screen.

Lewin, K. (1951). Problems of research in social psychology. In D. Cartwright. (Ed.), Field theory in social science (p. 169). New York: Harper and Row.

Leyens, J. P., \& Picus, S. (1973). Identification with the winner of a fight and name mediation: Their differential effects upon subsequent aggressive behavior. British Journal of Social and Clinical Psychology, 12, 374-377.

Lichter, S. R., \& Amundson, D. (1994). A day of TV violence 1992 vs. 1994. Washington, DC: Center for Media and Public Affairs.

Lieberman Research. (1975). Children's reactions to violent material on television-report to the American Broadcasting Company. New York: Lieberman Research.

Linder, J. R., \& Gentile, D. A. (under review). Is the television rating system valid? Indirect, verbal, and physical aggression in programs viewed by fifth grade girls and associations with behavior.

Linné, O. (1998). What do we know about European research on violence in the media? In U. Carlsson, \& C. von Feilitzen. (Eds), (Children and media violence (pp. 139-154). Göteborg, Sweden: The UNESCO International Clearninghouse on Children and Violence on the Screen.

Liss, M. B., Reinhardt, L. C., \& Fredriksen, S. (1983). TV heroes: The impact of rhetoric and deeds. Journal of Applied Developmental Psychology, 4, 175-187.

MacBeth, T. M. (2003). Media effects on societies and communities. In D. A. Gentile (Ed.), Media violence and children (pp. 39-55). Westport, CT: Praeger Press.

Martin, S., \& Oppenheim, K. (2007, March). Video gaming: General and pathological use. Trends \& Tudes, 6(3), 1-7.

McChesney, R. W. (2002). Children, globalization, and media policy. In U. Carlsson, \& C. von Feilitzen (Eds), Children, young people and media globalisation (pp. 23-32). Göteborg, Sweden: The UNESCO International Clearinghouse on Children and Violence on the Screen.

Medved, M. (1995, October). Hollywood's 3 big lies. Reader's Digest, pp. 155-159.

Motion Picture Association, 2006. U.S. Theatrical Market Statistics. Available: http://www.mpaa.org/ 2006-US-Theatrical-Market-Statistics-Report.pdf Accessed October 28, 2007.

Nathanson, A. I. (1999). Identifying and explaining the relationship between parental mediation and children's aggression. Communication Research, 26, 124-143.

National Commission on the Causes and Prevention of Violence. (1969). Commission statement on violence in television entertainment programs. Washington, DC: U.S. Government Printing Office.

National Institute of Mental Health. (1982). Television and behavior: Ten years of scientific progress and implications for the eighties (Vol. 1): Summary report. Washington, DC: U.S. Government Printing Office.

National Television Violence Study. (1997). Technical Report, 2. Thousand Oaks, CA: Sage.

National Television Violence Study. (1998). Technical Report, 3. Thousand Oaks, CA: Sage.

Olivar, M. B. (1994). Portrayals of Crime, Race, and Aggression in Reality-Based Police Shows: A content analysis. Journal of Broadcasting and Electronic Media, 3, 179-192.

Paik, H., \& Comstock, G. (1994). The effects of television violence on antisocial behavior: A metaanalysis. Communication Research, 21(4), 516-546. 
Palzer, C., \& Scheuer, A. (2003). Self-regulation, co-regulation \& public regulation. In U. Carlsson \& C. von Feilitzen (Eds), Promote or Protect? Perspectives on media literacy and media regulations (pp. 165-178). Göteborg, Sweden: The UNESCO International Clearinghouse on Children and Violence on the Screen.

Perloff, R. M. (2002). The third-person effect. In J. Bryant, \& D. Zillman (Eds.), Media effects: Advances in theory and research (pp. 489-506). Mahwah, NJ: Lawrence Erlbaum Associates.

Perry, D. G., \& Perry, L. C. (1976). Identification with film characters, covert aggressive verbalization, and reactions to film violence. Journal of Experimental Research in Personality, 10, 399-409.

Potter, W. J. (1999). On media violence. Thousand Oaks, CA: Sage.

Potter, W. J. (2003). The 11 Myths of Media Violence. Thousand Oaks, CA: Sage Publications.

Potter, W. J., \& Berry, M. (1999). Constructions of judgements of violence. Paper presented to the Annual Meeting of the International Communication Association, San Franciso, CA.

Potter, W. J., Vaughan, M. W., Warren, R., Howley, K., Land, A., \& Hagemeyer, J. C. (1995). How real is the portrayal of aggression in television entertainment programming? Journal of Broadcasting \& Electronic Media, 39, 496-516.

Potter, W. J., \& Ware, W. (1987). An analysis of the contexts of antisocial acts on prime time television. Communication Research, 14, 664-686.

Potter, W., Warren, R., Vaughn, M., Howley, K., Land, A., \& Hagemeyer, J. (1997). Antisocial acts in reality programming on television. Journal of Broadcasting and Electronic Media, 41, 69-89.

Proctor, R. W., \& Capaldi, E. J. (2006). Why science matters: Understanding the methods of psychological research. Malden, MA: Blackwell.

Rizzolatti, G., \& Craighero, L. (2004). The mirror-neuron system. Annual Review of Neuroscience, 27, 169-192.

Robinson, T. N., Wilde, M. L., Navracruz, L. C., Haydel, K. F., \& Varady, A. (2001). Effects of reducing children's television and video game use on aggressive behavior: A randomized controlled trial. Archives of Pediatric Adolescent Medicine, 155, 17-23.

Rosekrans, M. A., \& Hartup, W. W. (1967). Imitative influences of consistent and inconsistent response consequences to a model on aggressive behavior in children. Journal of Personality \& Social Psychology, 7(4), 429-434.

Rosenthal, R. (1990). How are we doing in soft psychology? American Psychologist, 45, 775-777.

Rule, B. G., \& Ferguson, T. J. (1986). The effects of media violence on attitudes, emotions, and cognitions. Journal of Social Issues, 42(3), 29-50.

Sanders, G. S., \& Baron, R. S. (1975). Pain cues and uncertainty as determinants of aggression in a situation involving repeated instigation. Journal of Personality and Social Psychology, 32, 495-502.

Saunders, K. W. (2003a). Regulating youth access to violent video games: Three responses to First Amendment concerns. Michigan State Law Review, 51, 51-114.

Saunders, K. W. (2003b). Saving Our Children from the First Amendment. New York: New York University Press.

Sebastian, R. J. (1978). Immediate and delayed effects of victim suffering on the attacker's aggression. Journal of Research in Personality, 12, 312-328.

Shaw, M. E., \& Costanzo, P. R. (1982). Theories of social psychology (pp. 3-18). New York: McGrawHill.

Shipard, S. (2003). A brief look at the regulation of the broadcast media in Australia. In U. Carlsson \& C. von Feilitzen (Eds), Promote or Protect? Perspectives on media literacy and media regulations (pp. 237-242). Göteborg, Sweden: The UNESCO International Clearinghouse on Children and Violence on the Screen.

Silvern, S. B., \& Williamson, P. A. (1987). The effects of video game play on young children's aggression, fantasy, and prosocial behavior. Journal of Applied Developmental Psychology, 8 , $453-462$.

Smith, S. L., Wilson, B. J., Kunkel, D., Linz, D., Potter, W. J., Colvin, C. M., \& Donnerstein, E. (1999). Violence in television programming overall: University of California, Santa Barbara study. In National television violence study (Vol. 3, pp. 5-220). Thousand Oaks, CA: Sage.

Taylor, S. P. (1967). Aggressive behavior and physiological arousal as a function of provocation and the tendency to inhibit aggression. Journal of Personality, 35, 297-310. 
Thompson, K. M., \& Haninger, K.(2001). Violence in E-rated video games. Journal of the American Medical Association, 286, 598-598.

Unsworth, G., Devilly, G. J., \& Ward, T. (2007). The effects of playing violent videogames on adolescents: Should parents be quaking in their boots? Psychology, Crime, \& Law, 13, 383394.

U.S. Department of Health and Human Services. (2001). Youth violence: A report of the Surgeon General. Rockville, MD: U.S. Department of Health and Human Services, Centers for Disease Control and Prevention, National Center for Injury Prevention and Control; Substance Abuse and Mental Health Services Administration, Center for Mental Health Services; and National Institutes of Health, National Institute of Mental Health.

U.S. Surgeon General's Scientific Advisory Committee on Television and Social Behavior. (1972). Television and growing up: The impact of televised violence. Washington, DC: U.S. Government Printing Office.

von Feilitzen, C. (1998). Introduction. In U. Carlsson \& C. von Feilitzen (Eds), Children and media violence (pp. 45-54). Göteborg, Sweden: The UNESCO International Clearinghouse on Children and Violence on the Screen.

von Feilitzen, C., \& Carlsson, U. (1999). Children and Media: Image Education Participation. Göteborg, Sweden: The UNESCO International Clearinghouse on Children and Violence on the Screen.

Walsh, D., Gentile, D. A., Walsh, E., Bennett, N., Robideau, B., Walsh, M., Strikland, S., \& McFadden, D. (2005). Tenth annual MediaWise ${ }^{\circledR}$ video game report card. Minneapolis, MN: National Institute on Media and the Family. Available: http://www.mediafamily.org/ research/report_vgrc_2005.shtml. Accessed: May 15, 2007.

Williams, T. M. (1986). The impact of television: A natural experiment in three communities. New York: Academic Press.

Wilson, B. J., Kunkel, D., Linz, D., Potter, J., Donnerstein, E., Smith, S. L., Blumenthal, E., \& Gray, T. (1997). Violence in television programming overall: University of California, Santa Barbara study. In M. Seawall. (Ed.), National television violence study (Vol. 1, pp. 3-184). Thousand Oaks, CA: Sage Publications.

Wilson, B. J., Kunkel, D., Linz, D., Potter, J., Donnerstein, E., Smith, S. L., Blumenthal, E., \& Berry, M. (1998). Violence in television programming overall: University of California, Santa Barbara study. In M. Seawall (Ed.), National television violence study (Vol. 2, pp. 3-204). Thousand Oaks, CA: Sage Publications.

Winters v. New York, 333 U.S. 507, 510 (1948). 